\title{
A sulfur isotopic profile through the Troodos ophiolite, Cyprus: Primary composition and the effects of seawater hydrothermal alteration
}

\author{
JEFFREY C. ALT \\ Department of Geological Sciences, 1006 C. C. Little Building, The University of Michigan, Ann Arbor, MI 48109-1063, USA
}

(Received April 20, 1993; accepted in revised form November 29, 1993)

\begin{abstract}
The sulfide mineralogy, sulfur contents, and sulfur isotopic compositions were determined for a section through the Troodos ophiolite, as represented by drillcore from Holes CY1A, CY2A, and CY4, plus selected outcrops, with the goals of understanding the geochemistry of S during hydrothermal altcration of the crust and obtaining a mass balance for sulfur in altered ophiolitic crust.

Primary $\delta^{34} S$ values of the ophiolite are $0-1 \%$, consistent with a MORB- or BAB-like sulfur source. The volcanic rocks have low sulfur contents $($ mean $=40 \mathrm{ppm})$ and generally negative $\delta^{34} \mathrm{~S}$ values (to $-26.1 \%$ ). These are the results of sulfur loss through oxidation by seawater at low temperatures $\left(<100^{\circ} \mathrm{C}\right)$ and isotopic fractionation during partial oxidation of igneous sulfides.

The sheeted dike complex is uniformly enriched in ${ }^{34} \mathrm{~S}\left(\delta^{34} \mathrm{~S}=5.4 \%\right)$ as the result of mixing of reduced Cretaceous seawater sulfate $(17 \%)$ with primary crustal sulfide. Sulfate was reduced through oxidation of ferrous iron in the dikes and conversion of igneous pyrrhotite to secondary pyrite. Decreasing water/ rock ratios with depth in the plutonic section led to a general decrease in $\delta^{34} \mathrm{~S}$ values downward to igneous values in the lower gabbros. Seawater effects are present locally to the base of the section, however. Cooling of diffuse upwelling hydrothermal fluids $\left(T>250^{\circ} \mathrm{C}\right)$ produced $\mathrm{S}$ and metal enrichments in the upper dikes ( $1.26 \mathrm{wt} \% \mathrm{~S}$ ), whereas sulfur was lost from the lower dikes and upper plutonic rocks (which contain $200 \mathrm{ppm}$ and $10-1640 \mathrm{ppm} \mathrm{S}$, respectively) through higher temperature $\left(>350^{\circ} \mathrm{C}\right)$ alteration reactions.

Epidosites at the dikes-gabbro transition contain $30 \mathrm{ppm} S$ with $\delta^{34} \mathrm{~S}=5.2-6.5 \%$. These rocks lost sulfur and metals during reaction with ${ }^{34}$ S-enriched deep hydrothermal fluids at high temperatures ( 350 $400^{\circ} \mathrm{C}$ ) and high water/rock ratios in basal hydrothermal upflow zones.

The ultimate effect of alteration of ophiolitic crust is redistribution of igneous sulfur within the crust and exchange of crustal sulfur for seawater sulfur, with little net change in the sulfur content of the crust overall. The bulk altered Troodos crust is enriched in ${ }^{34} \mathrm{~S}$, having $\delta^{34} \mathrm{~S}=3.6 \%$. Fluxes of sulfur between seawater and ophiolitic crust are an order of magnitude smaller than modern riverine input to and sedimentary sulfide output from the oceans. The amount of seawater sulfur that reacted with Troodos ophiolite crust is approximately twice that for a composite section of oceanic crust, consistent with the generally greater intensity of alteration of ophiolitic crust compared to modern oceanic crust.
\end{abstract}

\section{INTRODUCTION}

KNOWLEDGE OF THE DISTRIBUTION and isotopic composition of sulfur in oceanic and ophiolitic crust is important to understand the role that submarine hydrothermal systems play in the cycling of sulfur in the oceans through geologic time (EDMOND et al., 1979). Sulfur in volcanic glasses from midocean ridge basalts (MORB) has $\delta^{34} \mathrm{~S}$ values of $+0.1 \pm 0.5 \%$ (SAKAI et al., 1984), whereas present-day seawater sulfate has $\delta^{34} S=20,9 \%$ (REES et al., 1978), so isotopic exchange during hydrothermal alteration of ocean crust could significantly affect the compositions of these reservoirs. Sources of sulfur in volcanogenic massive sulfide deposits on the seafloor and in ophiolites can also be identified through examination of the geochemistry of sulfur in the deposits and associated crust. Subduction of altered ocean crust and sediment has been suggested to contribute to the ${ }^{34} \mathrm{~S}$-enrichment of arc volcanic rocks (WOODHEAD et al., 1987; ALT et al., 1993) and to sulfur isotopic heterogeneities in the mantle (HARMON et al,, 1987; CHAUSSIDON et al., 1987). Results for a composite section of altered oceanic crust, however, indicate that although sulfur is redistributed within the crust and some exchange with seawater occurs, there is little net change in the content or isotopic composition of sulfur in altered ocean crust (ALT et al., 1989; ALT and ANDERSON, 1991).

Pyrite from massive sulfide deposits in the Troodos ophiolite has $\delta^{34} S$ values ranging from -1.1 to $+7.5 \%$, but most fall between +4 and $+7 \%$ (CLARK, 1971; HUTCHINSON and SEARLE, 1971; JOHNSON, 1972; JAMIESON and LYDON, 1987). These values are significantly higher than those for modern mid-ocean ridge sulfide deposits, which average around $+3 \%$ (ARNOLD and SHEPPARD, 1981; STYRT et al., 1981; BLUTH and OHMOTO, 1988; SHANKS and SEYFRIED, 1987; WOODRIJF and SHANKS, 1988), suggesting the possibility of incorporation of greater amounts of seawater-derived sulfur in the ophiolite than in oceanic crust (ALT, 1991). The Troodos ophiolite originated in a subduction-related setting (RAUTENSCHLEIN et al., 1985), however, and islandare volcanic rocks have primary $\delta^{34} \mathrm{~S}$ valucs avcraging 4-5\% (UEDA and SAKAI, 1984; WOODHEAD et al., 1987; ALT et al., 1993), so the high $\delta^{34} \mathrm{~S}$ values of the Troodos sulfide deposits could reflect the presence of a ${ }^{34} \mathrm{~S}$-enriched arc-like primary sulfur component in Troodos crust (ALT, 1991).

Despite the data for sulfide deposits, little is known about the geochemistry of sulfur in ophiolitic crust, and a profile of sulfur in a complete section through ophiolitic crust is 
lacking. This paper presents data on sulfide mineralogy, sulfur contents, and sulfur isotopic compositions of a section through the Troodos ophiolite, Cyprus, as represented by drillcore from the Cyprus Crustal Study Project. The objectives of this work are to document the sulfide mineralogy, to understand the bchavior of sulfur during scawatcr-crustal reactions, and to obtain a mass and isotopic balance for sulfur in ophiolitic crust. The results for Troodos are compared with those for oceanic crust, and the question of the ${ }^{34} \mathrm{~S}$ enrichment of Troodos rocks and sulfide deposits relative to altered MORB is addressed.

\section{SAMPLING AND METHODS}

This work involved a suite of samples from a section through the Troodos ophiolite, Cyprus, as represented by drillcore from holes CY1A, CY2A, and CY4 and from well-characterized outcrops (Fig. 1). The Cretaceous Troodos ophiolite formed by seafloor spreading above a subduction zone (ROBINSON et al., 1983; RAIJTENSCHI.FIN et al., 1985). The upper gabbros, sheeted dikes, and lower (high-Ti series) volcanic rocks are interrelated and reflect seafloor spreading, whereas the upper (low-Ti series) extrusive rocks and the lower gabbros are related to a slower spreading event (THY et al., 1989), with corresponding low-Ti series dikes present in the dike complex (BARAGAR et al., 1989). Holes CY 1A and CY4 represent typical "background" alteration, whereas hole CY2A penetrates into a mineralized stockwork sulfide deposit and underlying hydrothermal upflow zone. Epidosites, representing deep hydrothermal reaction and basal upflow zones at the base of the sheeted dike section, plus associated diabases and high-level gabbros, were sampled from selected outcrops described by BICKLE and TEAGLE (1992). These were mainly collected from new roadcuts, and samples were carefully screened to be free of surficial weathering effects.

Hole CYIA penetrates $701.2 \mathrm{~m}$ : pillows and flows comprise the upper $200 \mathrm{~m}$, with dikes increasing in abundance downward into the upper sheeted dikes. The rocks mainly comprise a high-Ti andesitic to rhyodacitic series, but some low-Ti series basaltic andesites occur in the upper $200 \mathrm{~m}$ (BEDNARZ and SCHMINCKE, 1989). The core can be divided into two alteration zones, a low temperature $\left(<50^{\circ} \mathrm{C}\right)$ zone in the upper $250 \mathrm{~m}$ of mainly extrusives, with a transition over tens of meters to the underlying hydrothermally altered (lower

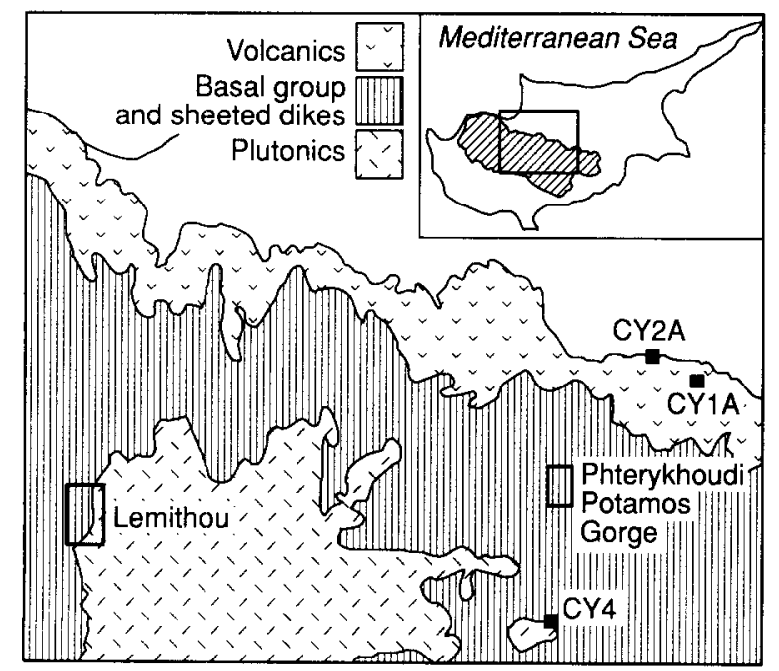

FIG. 1. Locations of drillholes CY1A, CY2A, and CY4 (solid squares) and locations of sampled outcrop areas (open boxes) in the Troodos ophiolite, Cyprus. Inset shows location of the Troodos ophiolite (hatchured area) on the island of Cyprus, and box in the inset indicates map area of the ophiolite shown in figure. greenschist) rocks of the upper dike zone (Fig. 2; BEDNARZ and SCHMINKE, 1989; GILLIS and ROBINSON, 1990). Hole CY4 penetrates a total of $2263 \mathrm{~m}$ (Fig. 2): $640 \mathrm{~m}$ of the lower sheeted dike complex; $690 \mathrm{~m}$ of upper gabbros and sporadic dikes; $424 \mathrm{~m}$ of lower gabbros: and $509 \mathrm{~m}$ of websteritic cumulates. The dikes consist of interfingered low- $\Gamma i$ and high-Ti series rocks altered to greenschist assemblages (BARAGAR et al., 1989). An intrusive contact occurs at $1330 \mathrm{~m}$ between the fine- to medium-grained upper gabbros and the mediumto coarse-grained lower gabbros, which grade into the underlying websteritic cumulates (THY et al., 1989). The plutonic section was altered under amphibolite facies conditions with superimposed greenschist and lower temperature alteration.

Hole CY2A penetrates $689 \mathrm{~m}$, through volcanic rocks and into underlying dikes. The upper $100 \mathrm{~m}$ comprise a low-Ti series of basaltic andesites, and below this is the high-Ti andesite-dacite series. The core can be divided into three alteration zones (Fig. 3 ): low-temperature $\left(<150^{\circ} \mathrm{C}\right)$ from 0 to $154 \mathrm{~m}$; stockwork sulfide mineralization from $154-300 \mathrm{~m}$; and lower greenschist grade hydrothermal alteration from 300 to $698 \mathrm{~m}$ (HERZIG and FRIEDRICH, 1987; CANN et al. 1987).

Samples were selected to be representative of the various types of rocks. The mineralogy was studied in a total of 143 polished thin sections, aided by SEM and energy-dispersive X-ray analyses. Representative $50-100 \mathrm{~g}$ samples were crushed in a steel jaw crusher and powdered in a tungsten carbide mill. Sulfur was extracted from wholerock powders using a stepwise technique. In the first step, monosulfide sulfur (e.g., pyrrhotite, pentlandite) was extracted by reacting the powders in $6 \mathrm{~N} \mathrm{HCl}$ at $80^{\circ} \mathrm{C}$ under nitrogen atmosphere for $1 \mathrm{~h}$. Nitrogen gas flowing through the reaction vessel carried any evolved $\mathrm{H}_{2} \mathrm{~S}$ into an $\mathrm{AgNO}_{3}$ trap, where sulfide was precipitated as $\mathrm{Ag}_{2} \mathrm{~S}$. In the second step, the residue from the first step was reacted with a $\mathrm{CrCl}_{2}+\mathrm{HCl}$ solution to extract "pyrite sulfur" (pyrite plus chalcopyrite), which was precipitated as $\mathrm{Ag}_{2} \mathrm{~S}$ (CANFIELD ct al., 1986). The solution from these steps was filtered, warmed to near boiling, and $\mathrm{BaCl}_{2}$ solution added to precipitate any soluble sulfate as $\mathrm{BaSO}_{4}$. Sulfur contents were determined gravimetrically using the various extractions. Sulfide minerals for isotopic analysis were also separated from veins, vugs, and massive sulfide intervals by handpicking.

$\mathrm{SO}_{2}$ gas for mass spectrometric analysis was prepared by combustion of sulfides with $\mathrm{Cu}_{2} \mathrm{O}$ under vacuum at $1000^{\circ} \mathrm{C}$. $\mathrm{SO}_{2}$ gas was analyzed for sulfur isotope ratios using a VG 602E instrument. Analyses are reported as standard $\delta$ notation relative to Canyon Diablo Troilite (CDT). Analytical uncertainties $(1 \sigma)$ are $\pm 0.2 \%$ for sulfides and $\pm 0.4 \%$ for sulfates based on multiple analyses of standards.

\section{RESULTS}

\section{Low Temperature Alteration of Volcanic Rocks in Holes CY1A and CY2A}

Volcanic rocks in the low temperature alteration zone (LTZ; $0-250 \mathrm{~m}$ ) in Hole CY1A and the upper $160 \mathrm{~m}$ of hole CY2A range from slightly (10\%) to totally (100\%) recrystallized to saponite ( $\mathrm{Mg}$-smectite), celadonite, iron oxyhydroxides, calcite, and zeolites. Sulfides are generally rare in the I.T7 of both cores, but are more abundant in the lower $100 \mathrm{~m}$ of the LTZ in CY1A. Round to irregular grains of pyrite \pm chalcopyrite \pm magnetite, generally $1-40 \mu \mathrm{m}$ in size, occur in interstitial areas and in vugs with saponite, celadonite, and calcite. Chalcopyrite is rarely rimmed by covellite. Some of these sulfides may be recrystallized igneous grains, but those filling pore spaces are clearly secondary. Sulfur contents are generally less than $150 \mathrm{ppm}$, but increase in the lower $100 \mathrm{~m}$ of the LTZ in CY1A (Table 1; Fig. 2). Pyrite is volumetrically the most abundant sulfide having $\delta^{34} \mathrm{~S}$ values of -26.1 to $4.0 \%$ ( ' 'able 1; Fig. 2). The higher sulfur contents at the base of the CY1A LTZ correspond with the presence of more abundant secondary pyrite \pm chalcopyrite replacing 


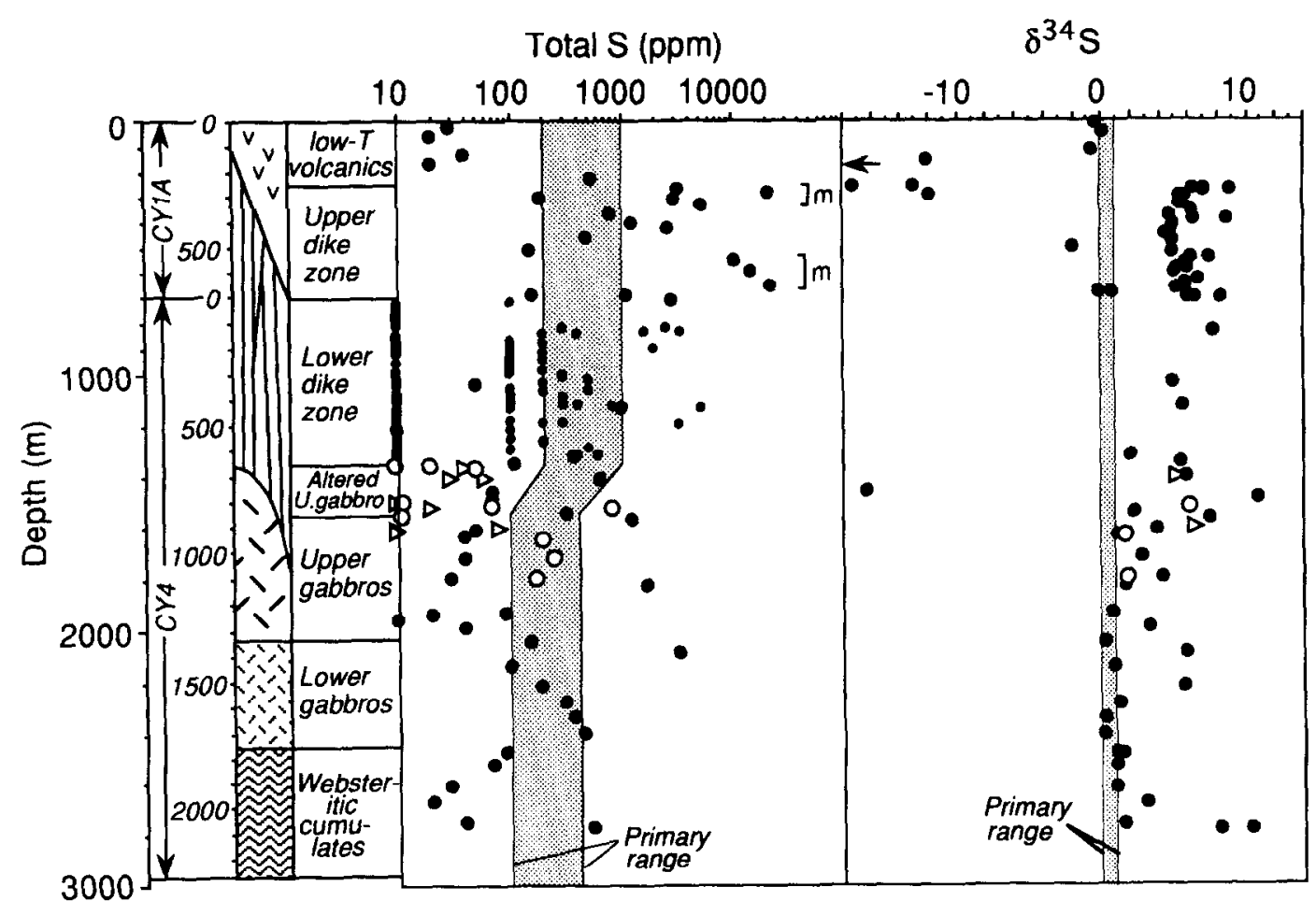

FIG. 2. Sulfur data for a section through the Troodos ophiolite as represented by holes CYIA and CY4. Lithology and alteration zones are shown at left. Data for drillcore from Table 1 plutled as large solid circles, epidosites plotted as open triangles, and other outcrop samples from Table 2 plotted as open circles. Data plotted as small solid circles from BARAGAR et al. (1989). Shaded areas represent inferred range of primary sulfur contents and $\delta^{34} \mathrm{~S}$ values. " $\mathrm{m}$ " indicates mineralized zones in the upper dikes. Arrow indicates sample that plots off scale $(-26.1 \%)$. See text for discussion.

silicates and in veins with chalcedony and quartz, and with more intensive alteration of the rocks.

\section{Hydrothermal Alteration of Dikes in Holes CY1A and CY4}

Below $250 \mathrm{~m}$ in hole CY1A, rocks from the upper dike zone are completely recrystallized to chlorite, albite, quartz, epidote, and sphene. Veins are filled with quartz and pyrite \pm pyrrhotite \pm chalcopyrite \pm epidote \pm chlorite. Common small, $1-50 \mu \mathrm{m}$ grains of pyrite and chalcopyrite in interstitial areas and included in plagioclase are most likely recrystallized igneous sulfides. Secondary pyrite is common as $5-500 \mu \mathrm{m}$ irregular grains replacing silicates and in vugs and veins, and contains $1-5 \mu \mathrm{m}$ inclusions of pyrrhotite and chalcopyrite. Chalcopyrite is much less abundant than pyrite, occurring as $\leq 100 \mu \mathrm{m}$ interstitial grains, filling vugs, replacing silicates, and as a minor component of veins in the lower section of the core $(>390 \mathrm{~m})$. Traces of late oxidation effects occur in some samples: hematite is present in three samples as pseudomorphs after tabular pyrrhotite in veins and vugs, and chalcopyrite is rimmed by bornite and covellite. Unmineralized zones from 315 to $538 \mathrm{~m}$ and 661 to $698 \mathrm{~m}$ contain 150-2740 ppm S, essentially all as pyrite-S (Table 1; Fig. 2 ). With the exception of a late post-hydrothermal alteration dike, $\delta^{34} \mathrm{~S}$ values for sulfide in unmineralized rocks range from -1.9 to $8.7 \%$, with a mean of $4.8 \pm 2.8 \%$.
Two mineralized intervals occur at 264-315 $\mathrm{m}$ and 538$661 \mathrm{~m}$ in the upper dike zone of CY $1 \mathrm{~A}$. These zones contain much greater abundances of sulfides and have high sulfur contents (3000-22000 ppm; Table 1; Fig. 2). The upper mineralized interval is characterized by 0.1 to $2 \mathrm{~cm}$ wide

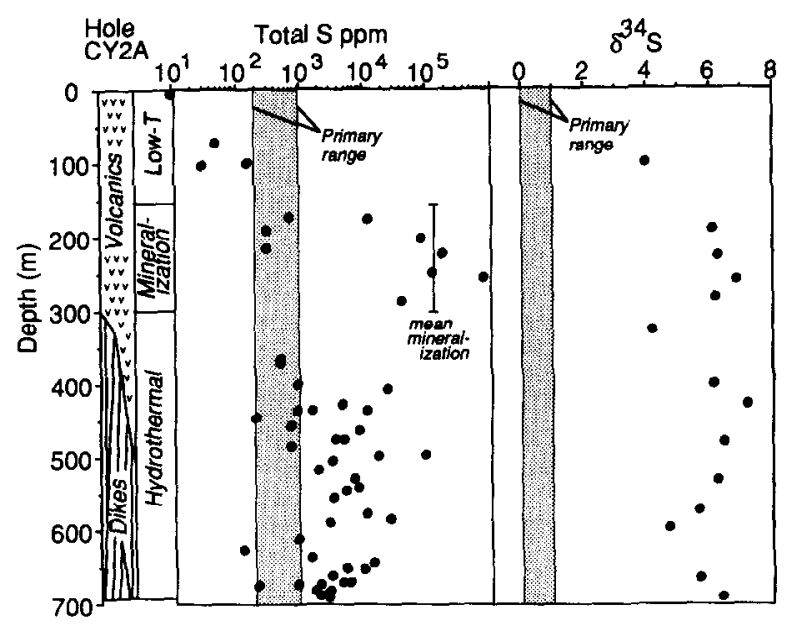

FIG. 3. Sulfur data, lithostratigraphy, and alteration zones for hole CY2A. Stockwork sulfide mineralization and underlying feeder zone have high sulfur contents and $\delta^{34} \mathrm{~S}$ values relative to inferred primary values (shaded areas). Vertical bar represents mean S content of stockwork sulfide mineralization (ADAMIDES, 1987). Data from Table 1, CANN et al. (1987) and JAMIESON and LYDON (1987). 
Table 1. Sulfur Data for Troodos Drillcore.

\begin{tabular}{|c|c|c|c|c|c|c|c|c|c|c|c|c|}
\hline & & & & & & & & & & 8345 & & \\
\hline & & & $\%$ & & Sulfur Con & ntent (on & m) & Bulk & lock & & & \\
\hline Hole & Samole & Type A & Alteration & $\mathrm{HCl}-\mathrm{S}$ & $\mathrm{S} \quad \mathrm{Py}-\mathrm{S}$ & SO4-S & Totals & $\mathrm{HCl}-\mathrm{S}$ & $\mathrm{Py}_{\mathrm{S}} \mathrm{S}$ & cein Dy & vue Dy & me co \\
\hline CY1A & 8.1 & p & 70 & - & 30 & T & 30 & & -0.4 & & & \\
\hline & 41.1 & f & 50 & - & 20 & 4 & 20 & & 0.1 & & & \\
\hline & 114.1 & $p$ & 40 & - & 40 & tI & 40 & & -0.7 & & & \\
\hline & 150.5 & f & 50 & - & 20 & tr & 20 & & -12.1 & & & \\
\hline & 210.7 & $\mathrm{db}$ & 100 & - & 540 & ir & 540 & & -26.1 & & & \\
\hline & 248.9 & $f$ & 100 & - & 3260 & - & 3260 & & -13.0 & -17.2 & & \\
\hline & 264.8 & p & 100 & 60 & 21120 & 30 & 21210 & 8.9 & 6.3 & & & \\
\hline & 266.0 & $\mathrm{~b}-\mathrm{m}$ & 100 & & & & & & & 7.1 & & \\
\hline & 269.9 & $\mathrm{p}-\mathrm{m}$ & 100 & & & & & & & 7.1 & & \\
\hline & 289.8 & $\mathrm{db}$ & 80 & - & 190 & - & 190 & & -11.9 & & & \\
\hline & 295.2 & $\mathrm{db}-\mathrm{m}$ & 100 & - & 2990 & 10 & 3000 & & 5.9 & & 5.5 & \\
\hline & 313.9 & $\mathrm{db}-\mathrm{m}$ & 100 & - & 5170 & - & 5170 & & 5.6 & & & \\
\hline & 332.9 & $\mathrm{db}-\mathrm{m}$ & 100 & & & & & & & 5.5 & & \\
\hline & 352.3 & $\mathrm{db}$ & 100 & - & 770 & 20 & 790 & & 6.2 & & & \\
\hline & 372.7 & f & 100 & & & & & & & 4.7 & & \\
\hline & 390.0 & $p$ & 100 & - & 1220 & - & 1220 & & 6.4 & & 8.7 & \\
\hline & 409.2 & $\mathrm{db}$ & 100 & - & 2570 & $\mathbf{t r}$ & 2570 & & 4.9 & & & \\
\hline & 430.7 & $\mathrm{db}$ & 100 & & & & & & & 4.8 & & \\
\hline & 448.8 & $\mathrm{p}$ & 100 & - & 490 & na & 490 & & 4.5 & & & \\
\hline & 475.2 & $\mathrm{db}$ & 100 & & & & & & & 4.9 & & \\
\hline & 497.7 & $\mathrm{db}$ & 100 & $\pi$ & 150 & - & 150 & & -1.9 & & & \\
\hline & 517.9 & $p$ & 100 & & & & & & & 5.0 & & \\
\hline & 538.7 & $f-m$ & 100 & $t$ & 10140 & $\mathbf{t}$ & 10140 & & 7.5 & 6.2 & & \\
\hline & 559.6 & $f-m$ & 100 & & & & & & & 5.9 & & \\
\hline & 582.1 & $\mathrm{db}-\mathrm{m}$ & 100 & - & 14180 & - & 14180 & & 5.2 & 6.0 & & \\
\hline & 599.4 & $\mathrm{db}-\mathrm{m}$ & 100 & & & & & & & 5.1 & & \\
\hline & 622.9 & $\mathrm{p}-\mathrm{m}$ & 100 & & & & & & & & 6.7 & \\
\hline & 641.6 & $\mathrm{db}-\mathrm{m}$ & 100 & $\pi$ & 21930 & 20 & 21950 & & 5.8 & & & \\
\hline & 651.7 & $\mathrm{db}-\mathrm{m}$ & 100 & & & & & & & 5.8 & & \\
\hline & 661.0 & $\mathrm{db}-\mathrm{m}$ & 100 & & & & & & & 5.2 & & \\
\hline & 675.3 & $\mathrm{db}$ & 100 & - & 1040 & 40 & 1080 & & 0.7 & & & \\
\hline & 675.5 & $\mathrm{db}$ & 100 & - & 160 & n.a. & 160 & & -0.1 & & & \\
\hline & 698.6 & $\mathrm{f}$ & 100 & $t$ & 2740 & $\mathrm{tr}$ & 2740 & & 6.0 & 6.5 & 6.5 & 8.3 \\
\hline CY4 & 125.40 & $\mathrm{db}$ & & & & & & & & 7.7 & & \\
\hline & 332.10 & $d b$ & 100 & - & 50 & tr & 50 & & 4.9 & & & \\
\hline & 420.70 & $d b$ & 100 & - & 980 & . & 980 & & 5.6 & & & \\
\hline & 509.20 & $d b$ & 100 & tr & 10 & tr & 10 & & & & & \\
\hline & 613.05 & $d b$ & 100 & $\pi$ & 370 & $\pi$ & 370 & & 2.0 & & & \\
\hline & 645.50 & $\mathrm{db}$ & 70 & tr & 110 & tr & 110 & & 5.5 & & & \\
\hline & 702.15 & $\mathrm{db}$ & 100 & 20 & 610 & - & 630 & & 5.9 & & & \\
\hline & 750.15 & $\mathrm{gb}$ & 90 & 10 & 60 & प & 70 & & -16.3 & & & \\
\hline & 780.20 & $\mathrm{db}-\mathrm{mg}$ & 90 & $t$ & 70 & - & 70 & & 10.8 & & & \\
\hline & 837.07 & $\mathrm{db}$ & 90 & 10 & 310 & 世 & 320 & & 2.3 & & & \\
\hline & 861.62 & gb & 100 & 10 & 1240 & tr & 1250 & & 7.5 & & & \\
\hline & 906.30 & $\mathrm{mg}$ & 50 & tr & 40 & 10 & 50 & & 3.8 & & & \\
\hline & 928.80 & $\mathrm{mg}$ & 60 & - & 40 & - & 40 & & 1.1 & & & \\
\hline & 1014.05 & $\mathrm{gb}$ & 40 & $t$ & 40 & tr & 40 & & 2.8 & & & \\
\hline & 1092.40 & $\mathrm{mg}$ & 10 & tr & 30 & tr & 30 & & 4.2 & & & \\
\hline & 1117.35 & $\mathrm{mg}$ & 10 & $t$ & 1640 & 0 & 1640 & & 1.6 & & & \\
\hline & 1230.30 & $\mathrm{gb}$ & 10 & $t$ & 90 & tr & 90 & & 0.7 & & & \\
\hline & 1238.50 & $\mathrm{gb}$ & 10 & 10 & 10 & tr & 20 & & & & & \\
\hline & 1255.20 & $\mathrm{gb}$ & 100 & $\pi$ & 10 & - & 10 & & & & & \\
\hline & 1282.70 & $\mathrm{gb}$ & 10 & $\pi$ & 40 & tr & 40 & & 3.3 & & & \\
\hline & 1345.65 & gb & 60 & $\pi$ & 140 & 10 & 150 & & 0.2 & & & \\
\hline & 1386.90 & $\mathrm{gb}$ & 40 & . & 3220 & tr & 3220 & & 5.9 & & & \\
\hline & 1436.00 & $\mathrm{gb}$ & 60 & - & 100 & $t$ & 100 & & 0.9 & & & \\
\hline & 1517.67 & $\mathrm{gb}$ & 70 & $\pi$ & 190 & na & 190 & & 5.7 & & & \\
\hline & 1577.50 & $\mathrm{gb}$ & 10 & प & 310 & II & 310 & & 12 & & & \\
\hline & 1637.22 & gb & 20 & 10 & 360 & tr & 370 & & 0.2 & & & \\
\hline & 1699.40 & $\mathrm{gb}$ & 30 & 10 & 440 & tr & 450 & & 0.1 & & & \\
\hline & 1778.00 & wb & 20 & 20 & 70 & $t$ & 90 & 1.3 & 1.0 & & & \\
\hline & 1825.20 & gb & 10 & tI & 70 & $\pi$ & 70 & & 1.0 & & & \\
\hline & 1909.40 & owb & 40 & 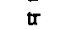 & 30 & $t$ & 30 & & 1.0 & & & \\
\hline & 1974.60 & wb & 30 & 10 & 10 & $\pi$ & 20 & & 3.0 & & & \\
\hline & 2052.20 & wb & 5 & - & 40 & - & 40 & & 1.5 & & & \\
\hline CY4 & 2074.60 & owb & 30 & 70 & 470 & $\mathbf{t}$ & 540 & 10.3 & 8.1 & & & \\
\hline CY2A & 5.35 & $\mathrm{f}$ & 60 & पt & 10 & - & 10 & & & & & \\
\hline & 69.99 & f & 60 & to & 30 & 20 & 50 & & & & & \\
\hline & 98.30 & $\mathrm{f}$ & 80 & $\pi$ & 150 &. & 150 & & 4.0 & & & \\
\hline & 101.38 & f & 80 & $\pi$ & 20 & 10 & 30 & & & & & \\
\hline & 186.25 & $\mathrm{f}-\mathrm{m}$ & & & & & & & & 6.1 & & \\
\hline & 223.10 & $f-m$ & & & & & & & & 6.3 & & \\
\hline & 255.10 & $\mathrm{p}-\mathrm{m}$ & & & & & & & 6.9 & & & \\
\hline & 278.50 & $\mathrm{f}-\mathrm{m}$ & & & & & & & 6.2 & & & \\
\hline & 322.86 & f & & & & & & & & 4.2 & & \\
\hline & 397.21 & $\mathrm{f}$ & & & & & & & & 6.1 & & \\
\hline & 425.10 & $\mathrm{db}$ & & & & & & & & 7.2 & & \\
\hline & 475.73 & $\mathrm{db}$ & & & & & & & & 6.5 & & \\
\hline & 526.45 & f & & & & & & & & 6.3 & & \\
\hline & 567.86 & $\mathrm{db}$ & & & & & & & 5.7 & & & \\
\hline & 591.85 & $\mathrm{db}$ & & & & & & & & 4.7 & & \\
\hline & 658.80 & $\mathrm{db}$ & & & & & & & & 5.7 & & \\
\hline & 684.60 & $\mathrm{db}$ & & & & & & & & 6.4 & & \\
\hline
\end{tabular}

Blanks=not analyzed; $t=t r a c e ;$ dash=none detected; $p=p i l l o w, ~ g l a s s ; ~ f=$ massive flow; $d b=$ diabase; $g b=g a b b r o ;$ $\mathrm{mg}=$ microgabbro; $\mathrm{wb}=$ =websterite; $o w b=$ olivine websterite; $\mathrm{m}=$ mineralized; $\mathrm{py}=$ pyrite; $\mathrm{cp}=$ chalcopyrite; Sample numbers correspond to depth in core (in meters). 
veins of pyrite + quartz, and by the presence of sphalerite. The sphalerite occurs as $20-200 \mu \mathrm{m}$ grains in vugs with chalcopyrite, chlorite, quartz, and pyrite, and as $1-20 \mu \mathrm{m}$ inclusions in pyrite. Sphalerite grains and inclusions are affected by chalcopyrite disease (i.e., they contain $<1$ to $2 \mu \mathrm{m}$ chalcopyrite inclusions around their edges and are partly rimmed and replaced by chalcopyrite). The lower mineralized interval is characterized by abundant chalcopyrite intergrown with pyrite and replacing silicates in porous aggregates, up to 300 $\mu \mathrm{m}$ in size. Chalcopyrite is also present as large (up to $1 \mathrm{~mm}$ ) crystals in vugs with chlorite, epidote, quartz, and pyrite, and is partly rimmed by bornite. $\delta^{34} \mathrm{~S}$ values of sulfide from the two mineralized zones average $6.1 \pm 0.7 \%$.

A late-stage, post-mineralization dike was sampled from within the upper mineralized zone at $289.8 \mathrm{~m}$. Igneous phases are altered to mixed-layer chlorite/smecite, fibrous zeolite, albite, quartz, and sphene. Pyrite and chalcopyrite are common as fine $(2-40 \mu \mathrm{m})$ interstitial grains. The sulfur content and $\delta{ }^{34} \mathrm{~S}$ of the dike are low (190 ppm and $-11.9 \%$ ) compared to the surrounding mineralized rocks (Table 1; Fig. 2).

Rocks in the basal dike section of hole CY4 (0-650 m) are nearly completely recrystallized to greenschist assemblages of amphibole (actinolitic hornblende, actinolite) plus minor quartz, chlorite, and epidote, with later zeolites and calcite (BARAGAR et al., 1989; THY et al., 1989). The dikes contain $1-40 \mu \mathrm{m}$ grains of pyrite \pm chalcopyrite \pm pyrrhotite \pm magnetite in interstitial areas and in altered silicates. Secondary pyrite and chalcopyrite are also present as 10-40 $\mu \mathrm{m}$ aggregates replacing silicates and igneous magnetite and in quartz + epidote veins. Sulfur contents of the lower dikes tend to be low, but range up to $980 \mathrm{ppm}$ (Fig. 2).$\delta^{34} \mathrm{~S}$ values of the basal dikes range from 2.0 to $7.7 \%$, with a mean of 5.1 $\pm 2.1 \%$ (Table 1 ; Fig. 2), similar to values for the upper dike section of hole CY1A.

\section{Hydrothermal Alteration of Plutonic Rocks in Hole CY4}

\section{Upper gabbros}

From 650 to $860 \mathrm{~m}$, the upper gabbros of hole CY4 are intensively hydrothermally altered (70-100\% recrystallized), whereas the underlying upper gabbros from $850-1350 \mathrm{~m}$ are less altered (10-70\% recrystallized). Orthopyroxene is partly replaced by amphibole, talc, and magnetite, and clinopyroxene is partly altered to brown and green hornblende, actinolite, and magnetite. Plagioclase is partly rccrystallized to albite, epidote, amphibole, chlorite, zeolites, and prehnite. Rare igneous Fe-Ti oxides are partly altered to sphene. Chlorite replaces the traces of olivine present, and veins are filled with amphibole, plagioclase, epidote, chlorite, zeolites, and rare late calcite and smectite.

Relict igneous sulfides are present as minor to rare phases in the upper gabbros. These consist of 2-150 $\mu \mathrm{m}$ globular aggregates and monomineralic grains of pyrite, pyrrhotite, chalcopyrite, and magnetite in interstitial areas and included in plagioclase, clinopyroxene, and orthopyroxene. Secondary sulfides generally occur in minor amounts in the upper gabbros, but they are locally abundant. Pyrite is most common as 3-200 $\mu \mathrm{m}$ porous, irregular grains in interstitial areas, replacing silicates, and intergrown with green amphibole.
Chalcopyrite occurs intergrown with pyrite in some samples, as $5-50 \mu \mathrm{m}$ grains in green amphibole, and is partly rimmed by bornite and covellite. Pyrrhotite is intergrown with pyrite and chalcopyrite in several samples, and marcasite is rarely present with interstitial pyrite. Veins of chlorite, amphibole, and late calcite contain pyritc, and small vcinlets of pyrite and chalcopyrite fill cracks along grain boundaries.

The more extensively altered upper gabbros (650-861 m) contain variable amounts of sulfur, $60-1240$ ppm S, essentially all as pyrite-S. Most of these samples have $\delta^{34} S$ values of 2.3-10.8\%, but one sample containing late low-temperature marcasite, pyrite, and smectite (CY4-750.15) has a value of $-16.3 \%$ (Table 1; Fig. 2). The deeper, less-altered upper gabbros ( $861-1330 \mathrm{~m}$ ) generally have low sulfur contents of $10-90 \mathrm{ppm}$, although one Fe-Ti oxide-rich diabase contains $1640 \mathrm{ppm} \mathrm{S}$ (Table 1; Fig. 2). $\delta^{34} \mathrm{~S}$ values range from 0.7 to $4.2 \%$. Relatively unaltered high-level gabbros sampled from outcrops contain $170-240 \mathrm{ppm} \mathrm{S}$, with $\delta^{34} \mathrm{~S}$ $=1.6-1.7 \%$ ( Table 2$)$.

\section{Lower gabbros and websteritic cumulates}

The rocks from 1330 to $2263 \mathrm{~m}$ are mostly slightly to moderately altered (10-50\% recrystallized). The secondary mineralogy is similar to that in the upper gabbros, but serpentine and magnetite are additionally present replacing olivine in the lower gabbros and websterites.

Recrystallized igneous sulfides in the lower gabbros are similar to those in the upper gabbros, but also include larger (to $300 \mu \mathrm{m}$ ) globular grains and aggregates of pyrrhotite \pm pyrite \pm chalcopyrite \pm magnetite \pm rare millerite in interstitial areas. Secondary sulfides in the lower gabbros are the same as in the upper gabbros and occur mainly in altered olivine and orthopyroxene. Larger $(0.1-5 \mathrm{~mm})$ masses of porous pyrite plus chalcopyrite rarely occur in interstitial areas and replacing silicates in the lower gabbros. Most of the lower gabbros contain $100-440 \mathrm{ppm} \mathrm{S}$, with generally decreasing sulfur contents upward (Table 1; Fig. 2). Sample CY41386.90 , however, contains visible millimeter sized pyrite in hand specimen and has a sulfur content of $3220 \mathrm{ppm} . \delta^{34} \mathrm{~S}$

Table 2. Sulfur Data for Troodos Outcrop Samples.

\begin{tabular}{|c|c|c|c|c|c|c|c|c|}
\hline \multirow{7}{*}{$\begin{array}{l}\text { Location } \\
\text { Phterykhoudi } \\
\text { Potamos Gorge }\end{array}$} & \multirow{3}{*}{ Sample } & \multirow{3}{*}{ Type } & \multirow{2}{*}{$\begin{array}{c}\% \\
\text { Alteration }\end{array}$} & \multicolumn{4}{|c|}{ Sulfur Content (pom) } & \multirow{3}{*}{$\begin{array}{c}\delta^{34} S \\
\text { Bulk Py-S }\end{array}$} \\
\hline & & & & $\mathrm{HCl}-\mathrm{S}$ & $\mathrm{Py}-\mathrm{S}$ & $\mathrm{SO}_{4}-\mathrm{S}$ & Total & \\
\hline & & & & & & & & \\
\hline & A7 & $\mathrm{db}$ & 100 & - & 10 & 10 & 20 & \\
\hline & A38 & $\mathrm{db}$ & 100 & - & 10 & & 10 & \\
\hline & A29 & $e p d b$ & 100 & - & 10 & 30 & 40 & \\
\hline & A30 & $\mathrm{db}$ & 100 & - & 10 & 40 & 50 & \\
\hline Lemithou & G1 & $\mathrm{mg}$ & 30 & - & 200 & $\mathbf{u}$ & 200 & 1.6 \\
\hline & G2 & $\mathrm{gb}$ & 20 & - & 240 & 10 & 250 & \\
\hline & G3 & gb & 30 & - & 130 & 40 & 170 & 1.7 \\
\hline & G6 & ep gb & 80 & - & 70 & 10 & 80 & 6.5 \\
\hline & G5 & ep gb & 100 & - & tr & 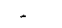 & $\pi$ & \\
\hline & $\mathrm{D} 32$ & ep gh & 100 & - & 10 & - & 10 & \\
\hline & K1 & dk-mar & 100 & - & 60 & - & 60 & 5.2 \\
\hline & $\mathrm{K} 2$ & ep db & 100 & - & 10 & 20 & 30 & \\
\hline & $\mathrm{J} 5$ & $\mathrm{mg}$ & 100 & - & tr & - & $\pi$ & \\
\hline & 36 & ep db & 10 & - & $\pi$ & 10 & 10 & \\
\hline & J7 & $d k$-mar & 90 & - & 10 & 60 & 70 & \\
\hline & D17 & late $\mathrm{dk}$ & 100 & - & 830 & - & 830 & 6.1 \\
\hline & D18 & dk-mar & 100 & - & 10 & or & 10 & \\
\hline & D19 & ep db & 100 & - & 10 & in & 20 & \\
\hline
\end{tabular}

$\mathrm{db}=$ diabase; $\mathrm{ep=epidosite;} \mathrm{gb}=\mathrm{gabbro} ; \mathrm{mg}=$ microgabbro; $\mathrm{dk}$-mar=dike margin. blanks=not analyzed; dashes=none detected, $t=t$ trace; Sample numbers correspond to those given in BICKLE and TEAGLE (1992). 
values range from 0.1 to $5.9 \%$, but most are less than $1.2 \%$ (Table 1; Fig. 2).

Igneous sulfides in the websterites are similar to those in the gabbros, but they lack pyrite and contain minor pentlandite and rare millerite. Olivine in the websterites is partly serpentinized, with the extent of alteration of the rock directly reflecting the amount of olivine originally present in the rock. Secondary sulfides are mainly restricted to altered orthopyroxene and olivine. Pyrrhotite and magnetite occur as 1-10 $\mu \mathrm{m}$ blebs in colorless amphibole and talc replacing orthopyroxene. Common $<1$ to $20 \mu \mathrm{m}$ grains of pyrrhotite, chalcopyrite, pentlandite, Co-pentlandite, linnaeite, awaruite (FeNi alloy), and wairauite (CoFe alloy) occur as isolated grains or intergrown with magnetite in serpentine replacing olivine. The websterites generally have low sulfur contents (20-70 ppm) and have $\delta^{34} \mathrm{~S}$ values of $1.0-3.0 \%$ (Table 1; Fig. 2). One serpentinized sample (CY4-2074.60) contains more sulfur and has a higher $\delta^{34} \mathrm{~S}$ value, however (540 ppm and $8.1-10.3 \%$, Table 1 ).

\section{Epidosites and Associated Rocks in Deep Hydrothermal Reaction/Upflow Zones}

Epidosites from outcrops of the basal dikes are totally recrystallized to quartz + epidote + sphene. Only traces of sulfide were observed: $1-10 \mu \mathrm{m}$ grains of pyrite, chalcopyrite, and pyrrhotite are included in and interstitial to quartz and epidote. Diabases and gabbros associated with the epidosites are replaced by hornblende, actinolite, albite, chlorite, sphene, quartz, and epidote, and contain sulfides similar to those in the epidosites. The epidosites have low sulfur contents $(<80$ $\mathrm{ppm}$ ), similar to the adjacent diabases and high-level gabbros (Table 2). Most samples did not contain sufficient sulfur to analyze isotopically, but one epidosite and a partly epidotized dike margin have $\delta^{34} \mathrm{~S}$ values of 6.5 and $5.2 \% 0$ (Table 2). A late dike at one epidosite locality contains $830 \mathrm{ppm} \mathrm{S}$ with $\delta^{34} \mathrm{~S}=6.1 \%$.

Despite careful screening of samples and collection of epidosites and associated rocks from outcrops along fresh roadcuts, these rocks could conceivably have been affected by oxidation during weathering. However, evidence suggests that weathering did not lead to significant changes in the sulfur contents or isotopic compositions of these rocks. First, the late dike retains a high sulfur content ( $830 \mathrm{ppm})$ and is from the same outcrop as low-S epidosites and associated rocks, suggesting that either all the rocks have retained their hydrothermal sulfur contents or that weathering effects were somehow highly selective. Second, the sulfur contents of the least altered ( $<40 \%$ recrystallized) gabbros from outcrops (mean $=206 \mathrm{ppm}$ ) are the same as those of the least altered gabbros from Hole CY4 $($ mean $=190 \mathrm{ppm})$, suggesting that weathering did not affect the outcrop samples. Finally, iron oxyhydroxides that might result from oxidation of sulfides are rare in the outcrop samples. Thus, the sulfur contents of the outcrop samples in Table 2 are accepted as their true values.

\section{Sulfide Mineralization and Hydrothermal Upwelling Zone in Hole CY2A}

The sulfide mineralogy of the CY2A mineralized and hydrothermally altered zones have been described by HERZIG and FRIEDRICH (1987). Sulfides are all of hydrothermal origin, and consist mainly of pyrite, pyrrhotite, and chalcopyrite, with minor sphalerite and traces of galena. Sulfur contents of mineralized rocks average $30 \%$, but range up to $45 \%$ (ADAMIDES, 1987), and the underlying hydrothermally altered rocks average $3.5 \% \mathrm{~S}$ (Fig. 3; CANN et al., 1987; JAMIESON and LYDON, 1987). Pyrite from the mineralized stockwork zone has uniform $\delta^{34} \mathrm{~S}$ values, with a mean of 6.4 $\pm 0.4 \%$ ( Table 1; Fig. 3 ). $\delta^{34} \mathrm{~S}$ values of pyrites in the underlying hydrothermally altered rocks are generally similar, but range to lower values (to $4.2 \%$; Table 1; Fig. 3 ).

\section{DISCUSSION}

\section{Primary Sulfur Contents and Isotopic Composition of the Troodos Ophiolite}

\section{Volcanic and dike sections}

Various geochemical evidence suggest that the Troodos ophiolite formed by seafloor spreading above a subduction zone (RoBINSON et al., 1983; RAUTENSCHLEIN et al., 1985). Unaltered volcanic glasses from the ophiolite have high $\mathrm{H}_{2} \mathrm{O}$ contents and high $\mathrm{H}_{2} \mathrm{O} / \mathrm{K}_{2} \mathrm{O}$ ratios, identical to back-arc basin (BAB) volcanic glasses and clearly distinct from MORB, ocean island basalts, and arc rocks, suggesting a $B A B$ setting for the ophiolite (MUENOw et al., 1990). Volcanic glass from the ophiolite contains 500-1000 ppm S, but only three samples of unaltered basaltic andesite and basalt glass were analyzed (MUENOw et al., 1990). If the BAB origin for Troodos is accepted, then data for modern BAB rocks can provide further constraints on the primary sulfur contents of Troodos volcanic rocks. Submarine basaltic to basaltic andesite glasses from the Mariana back-arc trough contain 200-930 ppm S (KUSAKABE et al., 1990; ALT et al., 1993), suggesting that the primary sulfur contents of Troodos lavas may have ranged to as low as $200 \mathrm{ppm}$. As the dikes are feeders for the volcanic

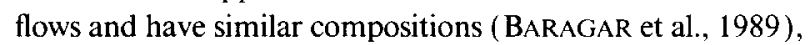
the dikes probably had similar primary sulfur contents.

Again, if the BAB setting for the origin of the ophiolite is accepted, then this suggests that the ophiolite rocks had primary $\delta^{34} \mathrm{~S}$ values similar to those of lavas from modern backarc basins, which average $0.3 \pm 1.0 \%$ (KUSAKABE et al., 1990; ALT et al., 1993). Additional evidence for such a value for the primary sulfur isotopic composition of the ophiolite comes from the results presented in this paper. As the intensity of alteration decreases downward in the gabbros and websterites of hole CY4 (Table 1; Fig. 2), $\delta^{34} \mathrm{~S}$ values approach those of unaltered MORB and BAB glasses, about 0 to $1 \%$. There is no evidence for a difference in primary sulfur isotopic composition between the upper (high-Ti series) and lower (low-Ti series) gabbros. Therefore, the range of $0-1 \%$ is taken as the primary sulfur isotopic composition of the Troodos ophiolite crust, consistent with derivation from a MORB or $\mathrm{BAB}$ mantle source.

\section{Plutonic rocks}

The plutonic rocks of the ophiolite are cumulates and do not represent liquid compositions as do the volcanic rocks and dikes. The websterites at the base of $\mathrm{CY} 4$ contain Nibearing sulfide assemblages (pentlandite, millerite), which 
are absent from the overlying gabbros. The Ni-bearing assemblages plus igneous sulfide inclusions in cumulate silicates are consistent with saturation of the magma and fractionation of sulfide as cumulate $\mathrm{Fe}-\mathrm{Ni}$-Cu sulfides in the websterites (CHAMBerlaiN, 1967; NALDRETT, 1981). The slightly altered rocks from the websteritic section that have $\delta^{34} \mathrm{~S}$ values within or near the assumed primary range $(0-1 \%$ ) all have sulfur contents less than $100 \mathrm{ppm}$ (Table 1), suggesting low primary sulfur contents for the websteritic section.

The abrupt increase in sulfur contents from the underlying websteritic cumulates to the base of the lower gabbros at $1750 \mathrm{~m}$ (Fig. 2) coincides with the appearance of plagioclase as a cumulate phase in the lower gabbros, but is most likely due to the faulted nature of the contact (MaLPAS et al., 1989). The high sulfur content of sample CY4-1386.90 (Table 1; Fig. 2) is attributed to the occurrence of abundant secondary pyrite associated with chlorite, epidote, and quartz, whereas the other rocks contain mainly igneous sulfides, so the sulfur contents of the latter $(100-450 \mathrm{ppm}$, mean $=260 \pm 140$ $\mathrm{ppm}$ ) probably closely reflect igneous values. Sulfur contents of slightly altered gabbros from outcrop (200-270 ppm; Table 2) are similar, supporting this suggestion. The generally upward-decreasing sulfur contents of the lower gabbros correlate with a systematic upward decrease in $\mathrm{Mg}$ numbers of orthopyroxene, clinopyroxene, and olivine, reflecting crystallization from progressively more Fe-rich differentiated liquids (Thy et al., 1989; MALPAS et al., 1989). Because the solubility of sulfide in mafic melts increases dramatically with total iron content (HAUGHTON et al., 1974), the upward decrease in sulfur contents of the lower gabbros reflects progressively increasing solubility of sulfur in the melt and its partitioning into the Fe-rich liquids from which the S-depleted cumulates formed. Indeed, swarms of diabase dikes from 1000-1100 m have low $\mathrm{Mg}$ numbers and high sulfur contents (e.g., CY4$1117.35=1640$ ppm; Table 1; Fig. 2), and are analogous to the Fe-rich liquids from which the low-S lower gabbros formed.

The generally elevated $\delta^{34} \mathrm{~S}$ values and intensive recrystallization of the upper gabbros (Fig. 2; Table 1) suggest the presence of a seawater sulfur component and that their sulfur contents no longer reflect igneous processes. Sample CY41230.3 is the least altered upper gabbro analyzed and its $\delta^{34} \mathrm{~S}$ value lies within the primary range of $0-1 \%$ for Troodos rocks ( Table 1), suggesting that its sulfur content of $90 \mathrm{ppm}$, which is close to the assumed primary range of $100-400 \mathrm{ppm}$, closely reflects the igneous value. The uppermost gabbros from 650 to $861 \mathrm{~m}$ are extensively hydrothermally altered, and their sulfur contents and high $\delta^{34} \mathrm{~S}$ values clearly do not represent igneous values (Table 1; Fig. 2).

\section{Mobility and Isotopic Fractionation of Sulfur During Low- Temperature Alteration of the Volcanic Section}

The volcanic rocks have lost sulfur relative to assumed igneous concentrations (Fig. 2), and generally contain less than $150 \mathrm{ppm} \mathrm{S}$. The low sulfur contents, general absence of sulfide minerals, abundance of Fe oxides, and high $\mathrm{Fe}^{3+}$, $\mathrm{Fe}^{\mathrm{T}}$ of the rocks $(\approx 0.7)$ all indicate loss of sulfur through oxidation of igneous sulfides during low-temperature $\left(<50^{\circ} \mathrm{C}\right)$ reaction with seawater at high seawater/rock ratios
( 100, i.e., "seafloor weathering"; GILLIS and ROBINSON, 1990). The increasing sulfur contents in the lower $100 \mathrm{~m}$ of the LTZ correspond to decreasing oxidation of the rocks (GILLIS and ROBINSON, 1990) and to greater abundances of sulfide minerals. This distribution is similar to that in oceanic crust, where the upper volcanic rocks are highly oxidized and have lost sulfur, whereas the lower volcanic section is less oxidized and has retained significant sulfur (ALT et al., 1989). The generally negative $\delta^{34} \mathrm{~S}$ values for Troodos volcanic rocks are also similar to those for altered volcanic rocks from the seafloor, which mostly range from -20 to $+2 \%$ (ANDREwS, 1979). The scatter to negative values is attributed to isotopic fractionation during partial oxidation of igneous sulfides (ANDREWS, 1979). This results in the formation of unstable intermediate sulfur compounds (sulfite, thiosulfate), which disproportionate into oxidized (sulfate) and reduced (sulfide) species. The sulfate is enriched in ${ }^{34} \mathrm{~S}$ and lost from the rock, whilst the sulfide is depleted in ${ }^{34} \mathrm{~S}$ and can combine with ferrous iron to form low- $\delta{ }^{34} \mathrm{~S}$ secondary sulfides in the rock. The similarity of the direction and magnitude of changes in sulfur content, $\delta^{34} \mathrm{~S}$, and oxidation in the Troodos volcanic section to those occurring in seafloor rocks, plus the agreement of $\mathrm{S}$ contents and $\delta^{34} \mathrm{~S}$ values of similar samples from outcrop and deep drillcore, indicate that the oxidation effects observed in the Troodos volcanic rocks are not the result of subaerial weathering.

The permeability decrease downward from volcanic rocks to dikes prevented significant penetration of cold seawater into the dikes, except locally along fractures, and caused a steep temperature gradient across this lithologic boundary (ALT et al., 1986; GILLIS and RoBINSON, 1990). Thus, sulfur removed from the volcanic rocks was lost to seawater during ridge-flank alteration in the upper portion of a cold convection cell that was open to seawater (Fig. 4).

\section{Anhydrite and Gypsum in Troodos Drillcore}

The simple process of heating seawater to the temperatures of hydrothermal altcration of the dikes $\left(250-350^{\circ} \mathrm{C}\right)$ should precipitate essentially all of the calcium and about one-third of the sulfate present in seawater as anhydrite (BISCHOFF and SEYFRIED, 1978). The occurrence of anhydrite in sheeted dikes from the seafloor is consistent with this process (ALT et al., 1989), so anhydrite precipitation was probably part of the process of hydrothermal alteration of ophiolitic crust. Although anhydrite and gypsum occur locally in the Troodos drillcore, these minerals are not related to seafloor hydrothermal processes.

Gypsum and trace amounts of anhydrite are present locally in holes CY4 and CY2A (HERZIG and FRIEDRICH, 1987; JAMIESON and LYDON, 1987; GILLIS and ROBINSON, 1990). These minerals have $\delta^{34} \mathrm{~S}$ values of 21.8 to $22.7 \%$ (JAMIESON and LYDON, 1987), significantly greater than the $17 \%$ value for Cretaceous seawater sulfate contemporaneous with formation of the ophiolite (CLAYPOOL et al., 1980). The ophiolite is overlain by sediments that include $150 \mathrm{~m}$ of upper Miocene evaporites (MALPAS and WILLIAMS, 1991) having $\delta^{34} \mathrm{~S}$ values of $+22 \%$ (CLAYPOOL et al., 1980), however, suggesting that gypsum and anhydrite in the drillcores formed from circulating post-obduction groundwaters that remobil- 
ized sulfate from the overlying evaporites. Late formation of gypsum and anhydrite in the drillcore is consistent with petrographic evidence, which shows that gypsum is part of the last stage of secondary minerals to form in vugs and veins, forming after late calcite and zeolites (GILLIS and ROBINSON, 1990). In contrast, anhydrite in ocean crust forms relatively early, when the rocks are still hot, probably within 100,000 years after formation of the crust (i.e., post-greenschist, but prior to off-axis formation of zeolites and calcite at lower temperature; ALT et al., 1986, 1989).

Anhydrite may have formed in Troodos crust during heating of seawater in the downwelling limb of an axial hydrothermal circulation cell, but because of the retrograde solubility of anhydrite, it was probably later dissolved by circulating fluids at lower temperatures (Fig. 4). Evidence for dissolution of anhydrite and replacement by calcite and zeolites at low temperatures has been observed in oceanic drillcore, and it is thought that most of the anhydrite formed in ocean crust undergoes such dissolution (ALT et al., 1986, 1989 ). Sulfur isotope data for hydrothermally altered samples indicate that, although some sulfate may have been lost from seawater as anhydrite during recharge in Troodos crust, seawater sulfate penetrated to higher temperatures and was reduced and incorporated into the ophiolitic crust as sulfide.

\section{Mineralogy and Mobility of Sulfur During Hydrothermal Alteration and Mineralization}

\section{Iydrothermally altered sheeted dikes}

The upper dikes in Hole CY $1 \mathrm{~A}$ have gained sulfur relative to inferred primary values (figure 2), and the two mineralized zones also exhibit elevated concentrations of $\mathrm{Zn}$ and $\mathrm{Cu}$ (GILLIS and Robinson, 1990). The occurrence of epidote and quartz plus metal- and S-enrichments throughout the upper dikes suggest the presence of highly reacted ( $\mathrm{Mg}$-depleted, $\mathrm{Ca}$ - and metal-enriched) hydrothermal fluids. The abundant quartz veins and sulfides in the upper mineralized zone plus the steep temperature gradient across the top of this zone inferred from the rapid change in mineralogy are consistent with cooling and mixing of upwelling hydrothermal fluids with colder seawater circulating in the overlying volcanic section (Fig. 4; GILlIS and ROBINSON, 1990). Similar disseminated sulfides and quartz veins occur at the volcanicdike transitions in the seafloor and in other ophiolites (ALT et al., 1986, 1989; HARPER et al., 1988), suggesting that these are typical features of ophiolitic and oceanic crust.

In contrast to the upper dikes, the lower dikes of Hole CY4 average only about $200 \mathrm{ppm}$ (Fig. 2), consistent with loss of sulfur to hydrothermal fluids. The generally low copper contents of the lower dikes (BARAGAR et al., 1989) and rarity of sulfide minerals in the rocks indicate breakdown of sulfides and loss of sulfur from the rocks. Amphibole (actinolite and actinolitic hornblende) is present in the lower dikes, but is absent from the upper dike zone of hole CY1A, suggesting that temperatures were greater in the lower dikes $\left(>300^{\circ} \mathrm{C}\right.$, up to $\left.\sim 400^{\circ} \mathrm{C}\right)$ than in the upper dikes $\left(>250^{\circ} \mathrm{C}\right.$; BIRD et al., 1984). Metals and sulfide are not significantly mobilized by hydrothermal fluids until temperatures greater than $350^{\circ} \mathrm{C}$
(SEEWALD and SEYFRIED, 1990), which is consistent with higher alteration temperatures and loss of metals and sulfur from the lower sheeted dikes.

Pyrite + chalcopyrite + pyrrhotite \pm magnetite was the stable mineral assemblage throughout the dike section, at temperatures $>250^{\circ}$ and probably approaching $400^{\circ} \mathrm{C}$ in the lower dikes. Minor partial reaction of these phases to hematite, bornite, and covellite occurred later at lower temperatures, under more oxidizing conditions.

\section{Plutonic section}

The plutonic rocks of hole CY4 were altered under a generally decreasing temperature hydrothermal regime (THY et al., 1989; VIBETTI et al., 1989), and secondary sulfide minerals are associated with all stages of silicate alteration. Re-

(a)
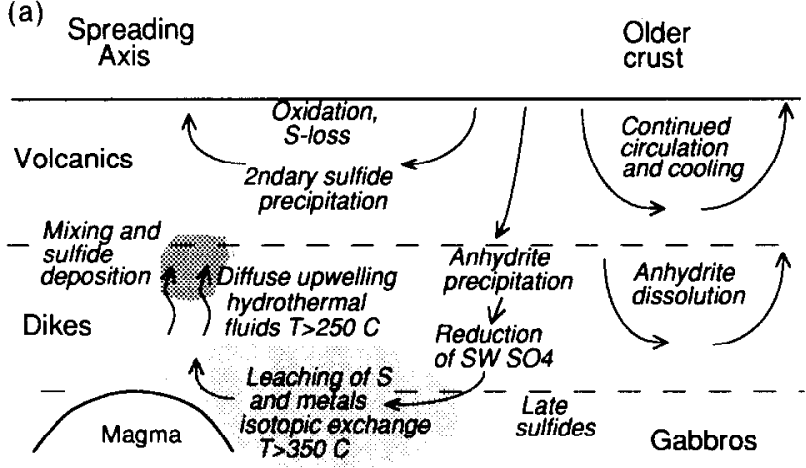

(b)

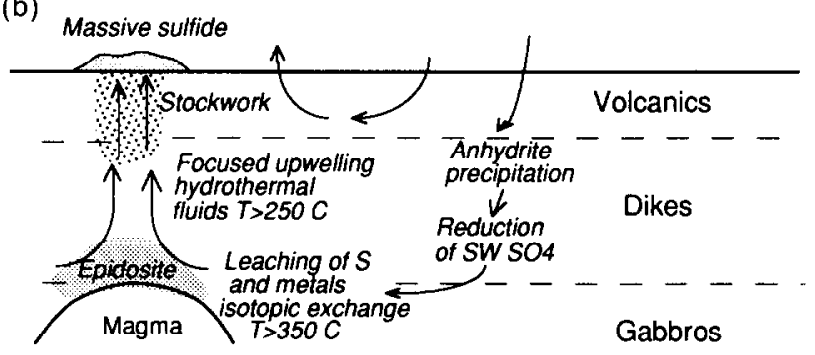

FiG. 4. Cartoons illustrating processes affecting sulfur during submarine hydrothermal alteration of Troodos ophiolite crust. (a) The volcanic section is open to seawater circulation, leading to oxidation of sulfides in the rocks at low temperatures $\left(<100^{\circ} \mathrm{C}\right)$ and loss of sulfur to seawater. Secondary sulfides precipitate locally, especially deeper in the volcanic section. Anhydrite precipitates as seawater is heated during recharge, but is later dissolved by cold seawater during continued off-axis circulation and cooling of the crust. Sulfate reduction occurs at $T>250^{\circ} \mathrm{C}$ at depth in the dikes and upper gabbros. Sulfur is lost from the lower dikes and upper gabbros to circulating fluids, and sulfides in the rocks equilibrate with hydrothermal solutions $\left(\delta^{34} \mathrm{~S}=5-6 \%\right.$ ). Diffuse upwelling hydrothermal solutions mix with seawater at the permeability contrast between dikes and volcanic rocks and deposit disseminated metal sulfides $\left(\delta^{34} S=5-6 \%\right)$. Late sulfides form locally in the upper gabbros as the system cools. (b) The same processes operate during formation of massive sulfide deposits in the ophiolite, but in a more intense and focused system. Greater leaching of sulfur occurs in the epidosite "reaction zone" above the magma chamber, and upwelling hydrothermal fluids are focussed and discharge at the seafloor, where they form massive sulfide deposits and S-rich stockwork feeder zones. 
placement of olivine and orthopyroxene by talc + magnetite + pyrite + chalocopyrite \pm pyrrhotite is related to early, high temperature $\left(500-600^{\circ} \mathrm{C}\right)$ hydration reactions at low water / rock ratios (ALT and ANDERSON, 1991). Pyrite + chalcopyrite \pm pyrrhotite \pm magnetite formed with brown and green hornblende at temperatures greater than about $400^{\circ} \mathrm{C}$; with chlorite and epidote that formed at $>250^{\circ} \mathrm{C}$; and locally with later, lower temperature prehnite and zeolites. Very late, low temperature oxidative alteration resulted in the local formation of trace pyrite and chalcopyrite with calcite, smectite, and iron oxyhydroxides, partial replacement of pyrrhotite by marcasite and pyrite, and rimming of chalcopyrite by bornite and covellite. These late, low-temperature reactions may have occurred on the seafloor (ALT and ANDERSON, 1991), or more recently through interaction with meteoric groundwaters. There are only traces of oxidation locally, and there is no evidence that this has significantly affected the sulfur contents or isotopic compositions of the rocks.

The uppermost gabbros from 650 to $861 \mathrm{~m}$ are essentially totally altered and exhibit both losses and gains of sulfur relative to igneous values of 100-400 ppm (Table 1; Fig. 2). The less altered upper gabbros from 861 to $1330 \mathrm{~m}$ have generally lost sulfur, containing less than $100 \mathrm{ppm} \mathrm{S}$. The only high sulfur content in this interval is for a slightly altered, Fe-Ti oxide-rich diabase dike (CY4 1117.35), whose high sulfur content reflects a high primary sulfur content. Oxygen isotope data indicate that the effects of seawater interaction are present throughout the section, but the intensity of alteration generally decreases downward in CY4 (VIBETTI et al., 1989). This is consistent with sulfur contents that more closely reflect igneous values in the lower gabbros (i.e., 100$400 \mathrm{ppm}$ from 1330 to $1750 \mathrm{~m}$ ). The one high sulfur content in this interval reflects the presence of secondary pyrite associated with late, lower temperature greenschist grade minerals (epidote, quartz, and chlorite). The local sulfur enrichments in the upper gabbros (samples CY4 702.15, 861.62) are also associated with late greenschist minerals (mainly epidote), and all of these S-enriched samples have elevated $\delta^{34} \mathrm{~S}$ values ( Table 1). These data suggest that sulfur was generally lost from the upper gabbros during high-temperature hydrothermal metamorphism at amphibolite conditions, but sulfur was later locally added to the rocks from lower temperature, more evolved hydrothermal fluids (Fig. 4). The latter process was probably related to waning of the hydrothermal system and cooling of hydrothermal fluids.

The websteritic cumulates exhibit some effects of hightemperature $\left(400-600^{\circ} \mathrm{C}\right.$ ) alteration (talc + magnetite, amphiboles), but the intensity of alteration of the rocks mainly reflects the serpentinization of olivine at lower temperatures. $\delta^{18} \mathrm{O}$ values of -0.9 to $+5.4 \%$ for $\mathrm{CY} 4$ serpentinites indicate temperatures of $100-300^{\circ} \mathrm{C}$ if formed in equilibrium with seawater (VIBETTI et al., 1989; WENNER and TAYLOR, 1973). The sulfide + oxide + metal alloy assemblages in the rocks are stable over this temperature interval (MISRA and FLEET, 1973; Craig et al., 1979; AbRAJANO and PASTERIS, 1989), although the millerite + pyrite associations indicate temperatures less than $200^{\circ} \mathrm{C}$ (CRAIG, 1973) and could have reequilibrated from higher temperatures. The presence of metal alloys (awaruite and wairauite) and relict olivine indicate very low water-rock ratios $(<0.5)$ and highly reducing conditions produced by the breakdown of water to $\mathrm{H}_{2}$ during serpentinization (ECKSTRAND, 1975; ABRAJANO and PASTERIS, 1989). There is no consistent trend of sulfur mobility with serpentinization: samples CY4-1909.4 and 2074.6 exhibit similar extents of serpentinization $(40-30 \%)$, but have very different sulfur contents ( 30 and 540 ppm, respectively; Table 1). This difference could be ascribed to differences in primary sulfur contents of the rocks, or to redistribution of sulfur as $\mathrm{H}_{2} \mathrm{~S}$ through reduction of metal sulfides to metal alloys during serpentinization (ECKSTRAND, 1975). The high $\delta^{34} \mathrm{~S}$ value of total sulfide in sample CY4-2074.6 (8.3\% ) suggests that neither alternative is adequate to explain the differences, and that seawater sulfur was added to the rock during serpentinization (see sulfur isotope section below).

\section{Deep reaction/upflow zones}

Epidosites and associated rocks from outcrops of the basal dikes-gabbro transition have low sulfur contents relative to igneous values (Table 2; Fig. 2). These rocks are highly altered (70-100\%) and contain only rare sulfide minerals, indicating loss of sulfur to hydrothermal fluids during recrystallization. The rocks are leached of copper and zinc and are interpreted to have been altered at high water/rock ratios $(\sim 1000)$ by highly reacted (metal- and $\mathrm{Ca}$-enriched, $\mathrm{Mg}$-depleted) hydrothermal fluids at temperatures of up to $400^{\circ} \mathrm{C}$ in the basal upwelling zone of an axial hydrothermal cell (RICHARDSON et al., 1987; SCHIFFMAN and SMTH, 1988; HARPER et al., 1988; SEYFRIED et al., 1988). Both high water/rock ratio and reaction at temperatures greater than $350^{\circ} \mathrm{C}$ significantly increase the amounts of metals and sulfur leached from the rocks (SEYFRIED et al., 1988; SEEWALD and SEYFRIED, 1990). Decreased pressure at temperatures near the critical point of seawater also enhances the solubility of metals and $\mathrm{H}_{2} \mathrm{~S}$, consistent with the location of epidosites in basal upwelling zones where fluids undergo decompression and leach metals and sulfur from the rocks (SEYFRIED et al., 1991). Despite loss of significant amounts of sulfur from these rocks, small amounts of pyrrhotite + chalcopyrite + pyrite are present in the epidosites, and the same minerals occur in associated altered diabases and gabbros. Experiments and thermodynamic models predict that seafloor vent fluids are in equilibrium with this same assemblage plus epidote and plagioclase solid solutions (SEYFRIED et al., 1991).

\section{Shallow upflow and sulfide mineralization in hole CY2A}

The stockwork sulfide mineralization in hole CY2A is interpreted to have formed below the seafloor, where upwelling, hot $\left(250-300^{\circ} \mathrm{C}\right)$ hydrothermal fluids cooled and mixed with colder seawater circulating in the overlying rocks (Fig. 4; HFRZIG and FRIFDRICH, 1987). The sulfide mineralized rocks and underlying dikes in CY2A have gained large amounts of sulfur relative to igneous values (Fig. 2), indicating that significant amounts of sulfur must have been added from seawater and/or transported from elsewhere in the crust. Calculations based on sulfur isotopic compositions of the rocks indicate that both processes occurred (see below). 


\section{Sulfur Isotopic Compositions and Sources of Sulfur in Hydrothermally Altered Rocks}

\section{Hydrothermal alteration of dikes and plutonic rocks}

The $\delta^{34} \mathrm{~S}$ values of sulfide in the hydrothermally altered Troodos dikes average about $5.4 \%$ (excluding one late posthydrothermal dike with $\delta^{34} \mathrm{~S}=-11.9 \%$; Table 1 ). Inorganic reduction of sulfate is kinetically inhibited at temperatures below $200-250^{\circ} \mathrm{C}$ but becomes important above about $250^{\circ} \mathrm{C}$ (SHANKs et al., 1981; OHMOTO and LASAGA, 1982). Alteration temperatures in the dikes were greater than $250^{\circ} \mathrm{C}$ (up to $\sim 400^{\circ} \mathrm{C}$ ), so simple closed-system reduction of seawater sulfate could account for the ${ }^{34} \mathrm{~S}$-enrichments of the dikes. Partial reduction of seawater sulfate could conceivably produce the observed $\delta^{34} \mathrm{~S}$ values of sulfides in Table 1: reduction of $45 \%$ of the sulfate present in Cretaceous seawater $\left(\delta^{34} \mathrm{~S}_{\text {sulfate }}\right.$ $=17 \%$ ) at a temperature of $300^{\circ} \mathrm{C}$ would yield sulfide with $\delta^{34} \mathrm{~S}_{\text {sulfide }}=5 \%$ and the residual seawater sulfate would have $\delta^{34} \mathrm{~S}_{\text {sulfate }}=26.9 \%$ (OHMOTO and RYE, 1979). This partial reduction process is unlikely, however, for several reasons. Throughout most of the hydrothermally altered Troodos rocks the stable sulfide + oxide assemblage was pyrite + chalcopyrite + pyrrhotite \pm magnetite. At the $\mathrm{pH}$ and $f_{\mathrm{O}_{2}}$ conditions indicated by this assemblage, essentially all sulfur in hydrothermal solutions in equilibrium with the assemblage should be present as sulfide (OHMOTO and RYE, 1979). At the high temperatures $\left(250-400^{\circ} \mathrm{C}\right)$ and acid $\mathrm{pH}$ inferred for seafloor hydrothermal solutions (DING and SEYFRIED, 1992), attainment of equilibrium between sulfate and sulfide in solution should be rapid, on the order of tens of days (OHMOTO and LASAGA, 1982), suggesting that sulfate would rapidly react to sulfide. Moreover, no evidence exists for partial reduction of seawater sulfate in hydrothermally altered rocks from the seafloor. Anhydrites in hydrothermally altered seafloor rocks have $\delta^{34} \mathrm{~S}$ values of modern seawater rather than the ${ }^{34} \mathrm{~S}$-enrichments that would be expected if they formed from fluids that had undergone partial sulfate reduction (ALT et al., 1989). Ion microprobe analyses of sulfide minerals in hydrothermally altered sheeted dikes from the seafloor reveal scatter of a few permil within individual samples, but they do not exhibit the wide range of $\delta^{34} \mathrm{~S}$ values, from near zero to $+20 \%$ or higher, that would result from a stepwise or progressive reduction of sulfate and precipitation of sulfide (AlT and Chaussidon, 1989). Thus, the ${ }^{34}$ S enrichments of the hydrothermally altered Troodos rocks compared to primary values are best explained as mixtures of completely reduced seawater sulfate with crustal sulfide. Although significant sulfate may have been lost from seawater through precipitation of anhydrite as seawater was heated during recharge into the crust, some seawater sulfate was present in solution as the fluids reached temperatures $>250^{\circ} \mathrm{C}$, where nearly complete sulfate reduction took place.

Seawater sulfate can be reduced during hydrothcrmal alteration of the crust through oxidation of ferrous iron or through conversion of igneous pyrrhotite to pyrite. SHANKS and SEYFRIED ( 1987) suggest that seawater sulfate is reduced during alteration of igneous pyrrhotite according to the reaction: $7 \mathrm{FeS}+8 \mathrm{H}++\mathrm{SO}_{4}^{2-}=4 \mathrm{FeS}_{2}+4 \mathrm{H}_{2} \mathrm{O}++3 \mathrm{Fe}^{21}$, with $\mathrm{H}^{+}$supplied by the formation of $\mathrm{OH}$-bearing secondary minerals, such as chlorite, talc, and amphibole. For igneous pyrrhotite with $\delta^{34} \mathrm{~S}_{\text {sulfide }}=0.1-1.0 \%$ interacting with Cretaceous seawater $\left(\delta^{34} \mathrm{~S}_{\text {sulfate }}=17 \%\right.$; CLAYPOOL et al., 1980) in the proportions given by the preceding equation, this process would produce secondary pyrite with $\delta^{34} \mathrm{~S}_{\text {pyrite }}=2.2-$ $3.0 \%$. This process could thus account for reduction of some seawater sulfate, but it cannot produce the observed $\delta^{34} \mathrm{~S}$ values of the Troodos dikes and upper gabbro sections (Fig. 2).

Oxidation of ferrous iron in the crust can provide the required additional sulfate reduction to produce the observed ${ }^{34} \mathrm{~S}$ enrichments. Seawater sulfate can be reduced through oxidation of ferrous iron in pyroxene or olivine (SHANKS et al., 1981) by reactions such as $8 \mathrm{Fe}^{2+}+10 \mathrm{H}^{+}+\mathrm{SO}_{4}^{2-}=8 \mathrm{Fe}^{3+}$ $+\mathrm{H}_{2} \mathrm{~S}+4 \mathrm{H}_{2} \mathrm{O}$, with $\mathrm{H}^{+}$supplied by formation of $\mathrm{OH}$-bearing minerals. Fresh volcanic glass from Troodos has $\mathrm{Fe}^{3+} / \mathrm{Fe}^{\mathrm{T}}$ $=0.14$ (RAUTENSCHLEIN et al., 1985), whereas the CY1A and $\mathrm{CY} 4$ dikes are oxidized and have $\mathrm{Fe}^{3+} / \mathrm{Fe}^{\mathrm{T}}$ values that average about 0.30 (BARAGAR et al., 1989; Gillis and ROBINSON, 1990). Assuming that all of this increased oxidation of iron in the dikes $\left(\mathrm{FeO}^{\mathrm{T}}=10 \mathrm{wt} \%\right)$ was caused by reduction of seawater sulfate, an additional $3 \times 10^{-5}$ moles of sulfate could be reduced per gram of rock, equivalent to $960 \mathrm{ppm}$ $\mathrm{S}$ in the rock. The Troodos dikes, weighted according to alteration type, average 2740 ppm S ( $650 \mathrm{~m}$ CY4 lower dikes, 250 ppm; $247 \mathrm{~m}$ CY1A upper dikes, 1150 ppm; and $204 \mathrm{~m}$ CY1A mineralized upper dikes, $1.26 \mathrm{wt} \% \mathrm{~S}$; Table 1). If 960 ppm, or $35 \%$, of this sulfur was derived from Cretaceous seawater sulfate, the sulfur in the rocks would have $\delta^{34} \mathrm{~S}$ $=6.3 \%$. These calculations show that oxidation of ferrous iron in the dikes can account for reduction of sufficient seawater sulfate to produce the measured sulfur isotopic compositions of the dikes (average $\delta^{34} \mathrm{~S}=5.4 \% 0$ ). Addition of $960 \mathrm{ppm} \mathrm{S}$ to the $200-1000 \mathrm{ppm}$ igneous sulfur present in the rocks cannot account for the high average sulfur contents of the dikes, however. The latter requires transfer of crustal plus seawater-derived sulfide from elsewhere in the crust.

$\delta^{34} \mathrm{~S}$ values exhibit a progressive decrease downward, from ${ }^{34} \mathrm{~S}$-enriched rocks in the dike section to igneous values in the lower plutonic section (Fig. 2). This trend corresponds to a change from whole-rock ${ }^{18} \mathrm{O}$ depletions and more intense alteration in the dikes to igneous oxygen isotope ratios and less intensive recrystallization in the lower $\mathrm{CY} 4$ plutonic rocks (Table 1; VIBETTl et al., 1989). All of these trends indicate a general decrease of the effects of seawater interaction downward in the plutonic section, although seawater alteration effects extend locally into the websteritic cumulates. Sulfate reduction reactions similar to those in the dikes also occurred in the plutonic section, but the smaller amounts of seawater interacting with the rocks limited the ${ }^{34} \mathrm{~S}$ enrichment of the resulting altered rocks.

Two samples from the hydrothermally altered zones, a late dike (CY1A-298.8) and a gabbro (CY4-750.15), have negative $\delta^{34} \mathrm{~S}$ values $(-11.9$ and $-16.3 \%$, respectively). These rocks both exhibit the effects of late, low-temperature alteration, characterized by the presence of pyrite and marcasite associated with smectite, calcite, iron oxyhydroxides, and zeolites. The secondary mineralogy and negative $\delta^{34} \mathrm{~S}$ values of these rocks are similar to those in the lower volcanic section, 
reflecting the same type of low-temperature partial oxidation, fractionation, and formation of secondary sulfides locally in the intrusive rocks. These effects are quite restricted in the dikes and plutonics, and occurred after axial hydrothermal alteration as indicated by replacement textures and crosscutting, low-temperature veins of smectite, pyrite, and marcasite. Similar local ${ }^{34} \mathrm{~S}$ depletions occur rarely in a section of oceanic gabbro (AIT and ANDFRSON, 1991).

The high $\delta^{34} \mathrm{~S}$ value of two partly serpentinized websterites (3.0 and 8.1-10.3\%; Table 1 ) suggest reaction with seawater or with hydrothermal fluids that contained a seawater-derived sulfide component. The high sulfur content and $\delta^{34} \mathrm{~S}$ of sample CY4-2074.60 (540 ppm and 8.3\% ) requirc the addition of relatively large amounts of seawater-derived sulfide, however. The presence of metal alloys and relict olivine indicate very low water / rock ratios $(\sim 0.5$; ABRAJANO and PASTERIS, 1989), but this ratio would require quantitative reduction and extraction of sulfate from seawater containing $16 \mathrm{mM}$ $\mathrm{SO}_{4}=$ or $60 \%$ of that originally present. This seawater-derived sulfide would have to be added to a rock already containing 290 ppm primary sulfur, compared with $\sim 100$ ppm $S$ for the least-altered websteritic samples (Table 1). A better explanation involves reduction of seawater sulfate plus redistribution of igneous sulfide during serpentinization. Breakdown of igneous sulfides to metal alloys during serpentinization released sulfide, which was combined with seawaterderived sulfide and concentrated in sample CY4-2074.60. Such mobility of sulfide during serpentinization is well documented (CHAMBERLAIN, 1967; ECKSTRAND, 1975).

\section{Epidosites and associated rocks in deep hydrothermal reaction/upflow zones}

The presence of pyrite + chalcopyrite + pyrrhotite + magnetite in epidosites and associated rocks suggests that essentially all sulfur in hydrothermal solutions was present as sulfide (OHмото and RYE, 1979). Given the $\delta^{34} \mathrm{~S}$ values of 5.2-6.5\% for these rocks and taking into account the slight fractionation between sulfide minerals and sulfide in solution at $350-400^{\circ} \mathrm{C}(-0.1$ to $+1.0 \%$, OHMOTO and RYE, 1979), sulfide in deep upwelling hydrothermal fluids in equilibrium with epidosites and associated rocks had $\delta^{34} \mathrm{~S}$ values of 4.2$6.6 \%$. Assuming a mixture of reduced Cretaceous seawater sulfate plus mobilized crustal sulfide implies the presence of evolved fluids containing significant amounts $(\sim 30 \%)$ of seawater-derived sulfide.

The epidosites are oxidized compared to unaltered rocks: $\mathrm{Fe}^{3+} / \mathrm{Fe}^{\mathrm{T}}=0.60$ vs. 0.14 , respectively (RAUTENSCHLEIN et al., 1985; RiCHARDSON et al., 1987). Oxidation of iron (FeO ${ }^{\mathrm{T}}$ $=10 \%$ for epidosites and fresh dikes) could have reduced $8.0 \times 10^{-5}$ moles of sulfate per gram of rock, or the equivalent of $2565 \mathrm{ppm}$ sulfur in the rocks. The epidosites have lost sulfur, however, so any sulfate that was reduced must have been removed by hydrothermal fluids. Alternatively, adiabatic decompression of seawater fluids near the critical point could have caused the observed oxidation of the rocks and formation of epidote through the breakdown of water and production of $\mathrm{H}_{2}$, without involving sulfate reduction (SEYFRIED et al., 1988). The latter suggests that hydrothermal fluids in the basal epidosite reaction / upflow zones could have already obtained their isotopic signature during reaction with dikes and gabbros elsewhere in the hydrothermal system. In either case, the sulfur isotopic compositions and sulfur contents of the epidosites reflect equilibration with hydrothermal fluids and leaching of sulfur from the rocks into circulating fluids, possibly with reduction of additional seawater sulfate.

\section{Shallow upflow and mineralization zones in $C Y 2 A$}

Temperatures of hydrothermal alteration and mineralization in the shallow upflow and mineralized zones of Hole CY2A ranged from $250-300^{\circ} \mathrm{C}$ (HERZIG and FRIEDRICH, 1987). Assuming that all sulfur in solution was present as sulfide, hydrothermal solutions in equilibrium with sulfide minerals from CY2A (Table 1 ) at $300^{\circ} \mathrm{C}$ would have had sulfide $\delta^{34} \mathrm{~S}$ of 4.0-6.7\% (OHMOTO and RYE, 1979). These values are identical to those for fluids in equilibrium with the epidosites and associated rocks in deep reaction/upflow zones, implying that little additional sulfate reduction occurred in shallow upflow or mineralized zones. This is in contrast to the increases in $\delta^{34} \mathrm{~S}$ attributed to sulfate reduction in shallow subseafloor mixing zones and seafloor sulfide deposits (JANECKY and SHANKS, 1988; ALT et al., 1989). The mixing process in crust sampled by hole CY2A may have been rapid enough to cause a sufficient temperature decrease that sulfate reduction was inhibited. A second possibility is that sulfate had been extracted from seawater during heating and precipitation of anhydrite in the area surrounding the upflow and mineralization zones before it could enter these zones. This process is similar to that occurring in hydrothermal systems on the Reykjanes peninsula on Iceland, where anhydrite precipitates and seals cracks as seawater penetrates laterally inward, thereby effectively sealing itself off from further penetration of seawater into the hydrothermal system (TOMASSON and KRISTMANNSDOTTIR, 1972).

JANECKY and SHANKS (1988) point out that sulfate reduction within seafloor sulfide chimneys, mounds, and stockwork feeder zones is a transient process that can causc increases in sulfide $\delta^{34} \mathrm{~S}$ of up to a few permil, but that the isotopic composition of sulfur in large sulfide ore deposits must be dominated by the composition of source rocks deep in the hydrothermal system. The latter appears likely for the Troodos system, where evidence for ${ }^{34} \mathrm{~S}$-enriched fluids extends to great depths in the ophiolitic section and includes the deep hydrothermal reaction/upflow zones, which are the "sources" for the mineralizing fluids.

Assuming all sulfur was present in solution as sulfide and that sulfur was derived from a mixture of reduced seawater sulfate plus crustal sulfide, $35 \%$ of the sulfide in the "feeder zone" underlying the mineralized rocks in hole CY2A ( 3.5 $\mathrm{wt} \%$ total sulfur) was derived from Cretaceous seawater. Reduction of this amount of sulfate by oxidation of ferrous iron in the rocks would require oxidation of more than twice the total amount of iron present in the rocks. Oxidation of iron in hydrothermal solutions and conversion of igneous pyrrhotite to pyrite can reduce small amounts of additional sulfate (JANECKY and SHANKS, 1988; SHANKS and SEYFRIED, 1987), but the high sulfur contents of the feeder zone and 
mineralization clearly require transport of crustal and seawater-derived sulfide from elsewhere in the ophiolite.

\section{Mass Balance of Sulfur in the Troodos Ophiolite}

One of the goals of this study is to understand the overall effect that seafloor alteration and hydrothermal processes had on sulfur in ophiolitic crust. The mineralized intervals in the upper dikes of hole CY1A comprise about $20 \%$ of the 1100 $\mathrm{m}$ thick composite dike section made up of combined holes CY1A and CY4 (Fig. 2). Similar mineralized zones appear to be a characteristic feature at the dike-volcanic transitions in other ophiolites and in ocean crust (ALT et al., 1986, 1989; HARPER et al., 1988). The amount of this type of mineralized rock is spatially heterogeneous, however, and averages only about 5\% of the dike section in the ophiolite (ADAMIDES, 1990). A budget for sulfur in altered Troodos crust, adjusted so that mineralized upper dikes comprise $5 \%$ of the dike section, is given in Table 3. Overall, the altered ophiolite crust exhibits no significant net change in sulfur content: sulfur is lost from the volcanic section, lower dikes and upper gabbros, but the sulfur gained by the upper dikes offsets these losses. The volcanic section was altered at high seawater/rock ratios in an upper, cold convection cell that was open to seawater (Fig. 4), so the sulfur lost from these rocks was lost to seawater. The sulfur gained by the intrusive section (dikes + plutonic rocks) must have come from elsewhere (laterally?) in the crust or from seawater. The isotopic data indicates input of seawater sulfur, and assuming a mixture of reduced Cretaceous seawater sulfur $\left(\delta^{34} \mathrm{~S}_{\text {Seawater }}=17 \%\right)$ and crustal sulfur $\left(\delta^{34} S_{\text {Primary }}=0.1-1.0 \%\right)$, the proportion of seawater sulfur can be calculated from $X \delta^{34} \mathrm{~S}_{\text {Primary }}+(1-X) \delta^{34} \mathrm{~S}_{\text {Seawater }}$ $=\delta^{34} \mathrm{~S}_{\text {Altered }}$, where $X$ is the fraction of crustal $\mathrm{S}, 1-X$ is the fraction of seawater sulfur, and $\delta^{34} S_{\text {Primary }}$ and $\delta{ }^{34} S_{\text {Alteced }}$ are the isotopic compositions of unaltered and altered rocks, re- spectively. Using the weighted mean $\delta^{34} \mathrm{~S}$ value for the intrusive section ( $5.0 \%$; Table 3 ) indicates that seawater sulfur comprises $25-29 \%$ of the sulfur in these rocks. This amount of seawater-derived sulfur can account for the sulfur gained by the intrusive section $\left(923 \times 10^{3} \mathrm{~g} \mathrm{~S} / \mathrm{m}^{2}\right.$; Table 3$)$ and is equivalent to the sulfur lost from the volcanic section to seawater $\left(889 \times 10^{3} \mathrm{~g} \mathrm{~S} / \mathrm{m}^{2}\right.$; Table 3$)$. Thus, the amount of sulfur lost to seawater during low-temperature alteration of the volcanic section is balanced by the sulfur gained through hydrothermal alteration of the intrusive section, resulting in no significant change in the sulfur content of ophiolitic crust. The $\delta^{34} \mathrm{~S}$ value of ophiolitic crust has increased through fixation of seawater sulfur in the crust, however, from a primary value of $0.1-1.0 \%$ to an altered value of $3.6 \%$ (Table 3 ).

Using the Troodos ophiolite as an analogue for ocean crust and knowing the current rate of production of oceanic crust ( $3 \mathrm{~km}^{2} / \mathrm{y}$; WILLIAMS and vON HERzEN, 1974), fluxes of sulfur resulting from seawater interaction with the crust can be calculated. Taking the data in Table 3, loss of sulfur from the volcanic scction would contribute $0.83 \times 10^{11} \mathrm{~mol} \mathrm{~S} / \mathrm{y}$ to seawater. The amount of seawater sulfur fixed in the Troodos intrusive section calculated above would provide a sink of $0.86 \times 10^{11} \mathrm{~mol}$ of seawater sulfur per year. These are clearly secondary fluxes compared to the river input to the oceans $\left(8.9 \times 10^{11} \mathrm{~mol} \mathrm{~S} / \mathrm{y}\right)$ and the output of sedimentary sulfide from the oceans $\left(5.5 \times 10^{11} \mathrm{~mol} \mathrm{~S} / \mathrm{y}\right.$; HoLSER et al., 1988).

Many small sulfide deposits and mineralized zones occur in the Toodos ophiolite, but are too small to be of economic value. These are analogous to the mineralized zones in the upper dikes of CY 1A, and their increased sulfur contents are probably derived from corresponding locally greater losses of sulfur from the lower dikes and gabbros, plus the seawater input. The economic sulfide deposits of the ophiolite require another sulfur source, however. Economically significant

Table 3. Sulfur Budget for the Troodos Ophiolite.

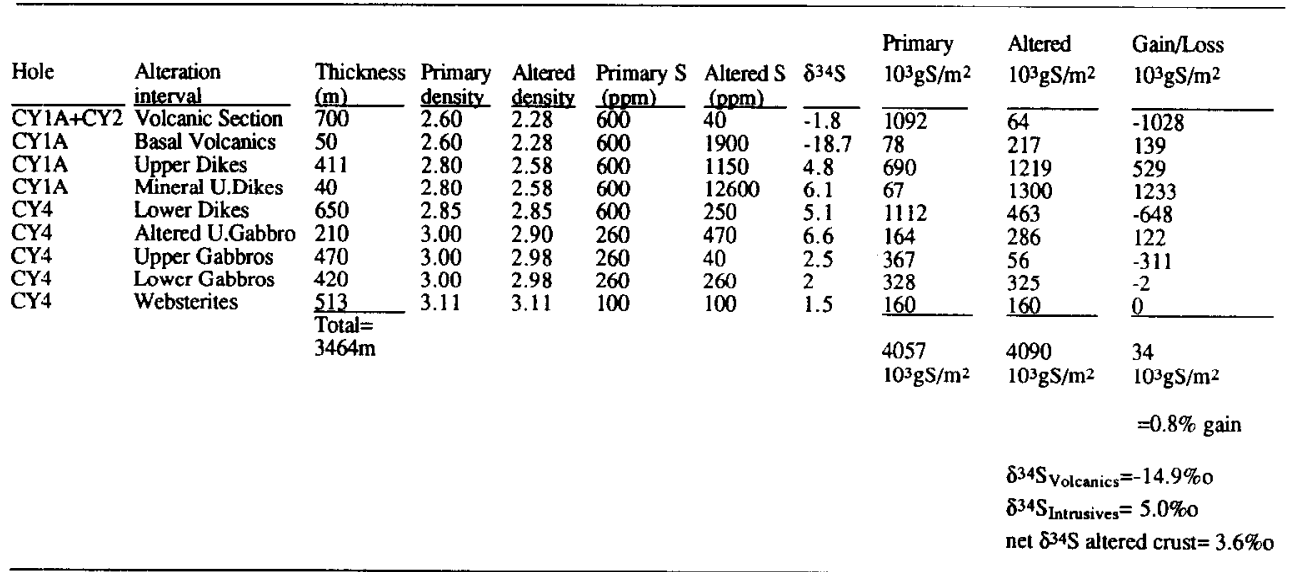

Budget assumes a $700 \mathrm{~m}$ thick volcanic section like those sampled by holes CY1A and CY2A, with the remainder made up of combined CY $1 A$ and CY4 dike and plutonic sections. Mean values of $S$ contents and 8345 values for each alteration interval are taken from Tables 1 and 2 and from BARAGAR et al, (1989). Densities are from SMITH and VINE $(1987 ; 1989 ; 1991)$. Primary $S$ contents are assumed based on evidence discussed in the text. Primary ${ }^{34} \mathrm{~S}$ values are taken as $0.1-1.0 \%$. $\delta^{34} \mathrm{~S}$ of altered crust $=\Sigma\left(\mathrm{m}_{\mathrm{i}} / \mathrm{m}_{\mathrm{t}}\right) 8^{34} \mathrm{~S}_{\mathrm{i}}$ summed over all alteration intervals, where $m_{i}$ is the mass of $S$ in alteration interval $i, m_{t}$ is the total mass of $S$ in the altered crustal section. and ${ }^{334} S_{i}$ is the $S$ isotopic composition of $S$ in alteration interval $i . \delta^{34} S_{V_{o l c a n i c s}}=\Sigma\left(m_{i} / m_{v}\right) \delta^{34} S_{i}$ summed over the volcanic and basal volcanic intervals, and $m_{v}$ is the mass of $S$ in the combined volcanic and basal volcanic intervals. $8{ }^{34} S_{\text {Intrusives }}$ was calculated similarly for the dike and plutonic intervals. 
massive sulfide deposits in the Troodos ophiolite vary in size from about $10^{4}-10^{7}$ tons of ore (ADAMIDES, 1987). Skouriotissa is the second-largest $\mathrm{Cu}$-producing deposit on Cyprus, containing an estimated $6 \times 10^{6}$ tons of ore at $48 \mathrm{wt} \% \mathrm{~S}$, or $2.88 \times 10^{12} \mathrm{~g} \mathrm{~S}$ (ADAMIDES, 1987). Pyrites from Skouriotissa have $\delta^{34} \mathrm{~S}$ values that average $7.1 \pm 0.4 \%$ (CLARK, 1971), and assuming a mixture of Cretaceous seawater and crustal sulfur, mass balance indicates about $40 \%$ seawater sulfur makes up the deposits. If $40 \%$ of the sulfur in Skouriostissa is seawater derived, then a crustal source of $1.73 \times 10^{12} \mathrm{~g} \mathrm{~S}$ is required to make up the balance. Alteration of a rock to epidosite releases about 570 ppm S (Table 2), so the crustal sulfur component in Skouriotissa could be provided by 1 $\mathrm{km}^{3}$ of epidosite. Outcrops of epidosite cover areas of 4-25 $\mathrm{km}^{2}$ (BETTISON-VARGA et al., 1992): if these epidosite zones are 40-250 $\mathrm{m}$ thick, which seems reasonable, then they can supply sufficient crustal sulfur to combine with seawater sulfur and form a Skouriotissa-sized sulfide deposit. Such large ore deposits are not taken into account in the sulfur budget in Table 3 , but their effect would be locally more intense redistribution of crustal sulfur within the ophiolite, plus an increase in the flux of seawater sulfur into the crust.

\section{Comparison with a Section of Oceanic Crust}

The same processes that affected sulfur in Troodos ophiolitic crust, of BAB origin, also occurred in a composite section of MORB crust (ALT et al., 1989; ALT and ANDERSON, 1991). Sulfur lost from hydrothermally altered oceanic gabbros and dikes is fixed, along with seawater-derived sulfide, in mineralized zones and sulfide deposits, and sulfur is lost from the volcanic section to seawater during low-temperature alteration. ${ }^{34} \mathrm{~S}$ enrichments of about $+3 \%$ ( up to $+6 \%$ ) occur locally in altered dikes and gabbros from the seafloor and are attributed to incorporation of reduced seawater sulfate in the crust, but these are restricted in occurrence and most of the oceanic dikes and gabbros do not exhibit the significant ${ }^{34} \mathrm{~S}$ enrichments shown by Troodos crust (ALT et al., 1989; ALT and ANDERSON, 1991). These data are consistent with modeling of seafloor vent fluids and hydrothermal water-rock interaction, which indicates that, although some sulfate reduction occurs locally at depth, sulfur is mainly rock-dominated during hydrothermal alteration of ocean crust and that sulfide in deep upwelling hydrothermal fluids has $\delta^{34} \mathrm{~S}$ values of about +1\% (JANECKY and SHANKS, 1988; BOWERS, 1989). Reduction of additional seawater sulfate in the shallow subsurface around the seafloor vents, in the walls of sulfide chimneys, and in subsurface mineralized zones gives rise to the higher $\delta^{34} \mathrm{~S}$ values of sulfide in the vent fluids, sulfide deposits, and mineralized zones (0.9-7.4\% ; SHANKS and SEYFRIED, 1987; JANECKY and SHANKS, 1988; WOODRUFF and SHANKS, 1988; ALT et al., 1989).

The predictions of more rock-dominatcd sulfide with low $\delta^{34} \mathrm{~S}$ in deep and upwelling mid-oceanic ridge hydrothermal fluids are in contrast to the high $\delta^{34} \mathrm{~S}$ values $(4.2-6.6 \% 0$ ) for epidosites and for deep upwelling hydrothermal fluids in Troodos crust. Similarly, the restricted and relatively small ${ }^{34} \mathrm{~S}$ enrichments of oceanic dikes and gabbros differ from the overall and higher ${ }^{34} \mathrm{~S}$ enrichments throughout the Troodos dikes and upper plutonic section. All of these data indicate that Troodos rocks interacted with greater amounts of seawater than did ocean crust.

Making the same sort of mass balance for oceanic crust as in Table 3, the net sink for seawater sulfur in hydrothermally altered ocean crust is $0.4 \times 10^{11} \mathrm{~mol} \mathrm{~S} / \mathrm{y}$, or only half that for Troodos crust, whereas the estimated flux from oceanic volcanic rocks to seawater is identical to that for Troodos (data from ALT et al., 1989; ALT and ANDERSON, 1991). Altered oceanic crust has bulk $\delta^{34} \mathrm{~S} \sim 1 \%$, compared to $3.6 \%$ for Troodos crust. Although the seawater flux into hydrothermally altered ocean crust is half that for Troodos, the change in bulk $\delta^{34} \mathrm{~S}$ from igneous to altered ocean crust is less than one-third that for Troodos. This is because oceanic crust contains greater amounts of primary sulfur than Troodos (about $900 \mathrm{ppm} \mathrm{S}$ in MORB compared to an inferred average of $600 \mathrm{ppm}$ in Troodos volcanics and dikes), so it takes proportionally less seawater-derived sulfur to make a comparable change in the bulk $\delta^{34} \mathrm{~S}$ of Troodos crust. A competing effect is that Cretaceous seawater sulfate had lower $\delta^{34} \mathrm{~S}(17 \%$ ) than present seawater $(21 \%$; REES et al., 1978; ClAYPOOL et al., 1980). In any case, assuming that sulfate concentrations in Cretaceous seawater were similar to modern seawater, the sulfur mass balances indicate that Troodos crust incorporated about twice the amount of seawater than the oceanic crustal section did. Similar results are obtained using strontium isotope ratios for oceanic and Troodos sheeted dike sections (FRIEDRICHSEN, 1985; GILLIS and ROBINSON, 1990), and both are consistent with the generally greater amounts of recrystallization of Troodos crust compared to oceanic crust (Table 1; ALT et al., 1986; ALT and ANDERSON, 1991).

This points out a fundamental difference between ophiolites and ocean crust: the ophiolite rocks in general, and the sheeted dikes in particular, are generally more intensively altered than ocean crust (Table 1; ALt et al., 1986; GILLIS and RoBinson, 1990; Gillis and THOMPSON, 1993). These differences may arise in part because of the differing tectonic settings (MORB vs. subduction-related, e.g., BAB), and conscquent structural influence on hydrothermal circulation. Supra-subduction zone ophiolites had higher primary volatile contents which led to higher vesicularity and hence porosity and permeability that could have enhanced alteration. Expelled magmatic volatiles could also have led to local "autometamorphism" of lower dikes and plutonic rocks ( KELLEY and ROBINSON, 1990). Although the processes affecting sulfur in oceanic and ophiolitic sections are remarkably similar, the difference in the magnitudes of the calculated fluxes points out the need for caution in applying results from ophiolites to ocean crust.

\section{SUMMARY AND CONCLUSIONS}

The sulfide mineralogy, sulfur contents, and sulfur isotope compositions have been determined for a section through the Troodos ophiolite, as represented by drillcore from Holes CY1A, CY2A, and CY4, plus selected outcrops. Rocks of the volcanic and dike sections contained 200-1000 ppm primary sulfur and the plutonic rocks contained $100-400 \mathrm{ppm}$ primary sulfur. Primary $\delta^{34} \mathrm{~S}$ values were $0-1 \%$, consistent 
with a back-arc basin sulfur source. Fractional crystallization of sulfide from a silicate liquid resulted in the presence of pentlandite-bearing igneous sulfide assemblages in websteritic cumulates and pentlandite-free assemblages in the gabbros. During silicate differentiation sulfur was increasingly partitioned into the progressively more Fe-rich silicate liquid, causing an upward decrease in sulfur contents of the lower gabbros.

The volcanic rocks average about $40 \mathrm{ppm} \mathrm{S}$, and have lost significant amounts of sulfur to seawater through oxidation at low temperatures $\left(<100^{\circ} \mathrm{C}\right)$ and high seawater/rock ratios. Minor secondary pyrite and chalcopyrite have generally negative $\delta^{34} \mathrm{~S}$ values $(-26.1$ to $4 \%$, which are attributed to isotopic fractionation during partial oxidation of igneous sulfides at low temperatures $\left(<100^{\circ} \mathrm{C}\right)$.

The upper dike zone of Hole CY 1A is enriched in sulfur and ${ }^{34} \mathrm{~S}$, averaging 1150 and $4.8 \%$, respectively. Two mineralized intervals comprise about $20 \%$ of the upper dike zone and contain $1.26 \mathrm{wt} \% \mathrm{~S}$ with $\delta^{34} \mathrm{~S}=6.1 \%$. The sulfur and ${ }^{34} \mathrm{~S}$-enrichments of the upper dikes were produced by cooling of diffuse upwelling hydrothermal fluids $\left(T>250^{\circ} \mathrm{C}\right)$ at the transition from dikes to the volcanic section, and mixing of these fluids with colder seawater circulating in the overlying volcanic rocks. Higher alteration temperatures (up to $\sim 400^{\circ} \mathrm{C}$ ) in the lower dikes of hole CY 4 resulted in losses of sulfur from these rocks (mean $S$ content $=200 \mathrm{ppm}$ ) to hydrothermal fluids. $\delta^{34} \mathrm{~S}$ values of the lower dikes are similar to those of the upper dikes, averaging $5.1 \%$. The ${ }^{34} \mathrm{~S}$ enrichments throughout the dike section are caused by incorporation of seawater-derived sulfide. Seawater sulfate was reduced by conversion of igneous pyrrhotite to secondary pyrite and by oxidation of ferrous iron in the dikes.

The upper gabbros generally lost sulfur during amphibolite grade hydrothermal metamorphism, but local sulfur enrichments, particularly in the uppermost $200 \mathrm{~m}$, occurred in the gabbros during later superimposed greenschist grade alteration, probably in response to waning of the hydrothermal system and cooling of hydrothermal fluids. The upper gabbros are enriched in ${ }^{34} \mathrm{~S}$, with $\delta^{34} \mathrm{~S}$ values up to $10.8 \%$ indicating incorporation of sulfide derived from reduction of seawater sulfate. $\delta^{34} \mathrm{~S}$ values decrease downward to inferred igneous values of $0-1 \%$ in the lower plutonic section, however, corresponding to a generally decreasing seawater/rock ratio with depth.

The websterites were locally serpentinized at temperatures of $100-300^{\circ} \mathrm{C}$ and low water/ rock ratios. Sulfur lost through breakdown of igneous sulfides to metal alloys (awaruite, wairauite) during serpentinization was redistributed in the websterites leading to local sulfur increases. Elevated $\delta^{34} \mathrm{~S}$ values, up to $8.3 \%$, occur locally and suggest incorporation of seawater-derived sulfur in the rocks.

Epidosites and associated rocks have low sulfur contents (30 ppm) and high $\delta^{34} \mathrm{~S}$ values $(5.2-6.5 \%)$. Alteration at high temperatures $\left(350-400^{\circ} \mathrm{C}\right)$ and high water/rock ratios in the basal upflow zone of a hydrothermal cell leached metals and sulfur from the rocks. Sulfides in the rocks equilibrated with deep hydrothermal fluids that had $\delta^{34} S$ values of $4.2-6.6 \%$.

The shallow upflow feeder zone and subsurface sulfide deposit of hole $\mathrm{CY} 2 \mathrm{~A}$ contain 3.5 and $30 \mathrm{wt} \% \mathrm{~S}$, respectively
The average $\delta^{34} \mathrm{~S}$ of $6.0 \%$ for these rocks indicates that Cretaceous seawater-derived sulfide comprises approximately $35 \%$ of the sulfur present. Some seawater sulfate reduction occurred in these rocks, but they also incorporated remobilized crustal sulfur and reduced seawater sulfur transported from elsewhere in the crust. Sulfur in large massive sulfide ore deposits can be accounted for by the sulfur lost from epidosites if about $30-40 \%$ of the sulfur present in the deposits is derived from seawater.

A mass balance for sulfur in Troodos crust indicates that the sulfur increase in the upper dike zone can be accounted for by crustal sulfur transported from the lower dikes and upper gabbros, plus addition of reduced Cretaceous seawater sulfur, which comprises $25-30 \%$ of the sulfur present in the hydrothermally altered intrusive (dike + plutonic) section. These processes result in a net addition of sulfur to the intrusive section, which is balanced by the sulfur lost to seawater from the volcanic section. The ultimate effect of alteration of ophiolitic crust is redistribution of igneous sulfur within the crust and exchange of crustal sulfur for seawater sulfur, yielding enrichment of ${ }^{34} \mathrm{~S}$ in average altered Troodos crust $\left(\delta^{34} \mathrm{~S}=3.6 \%\right)$. The sulfur fluxes into and out of the ophiolite crust from seawater are an order of magnitude smaller than fluxes of modern riverine input and sedimentary pyrite output to the oceans. The same processes occur in oceanic and ophiolitic crust, but the hydrothermally altered intrusive portion of Troodos crust reacted with about twice the amount of seawater that affected altered ocean crust, which has bulk $\delta^{34} \mathrm{~S}=1 \%$, and greater ${ }^{34} \mathrm{~S}$ enrichments extend deeper in Troodos than in ocean crust.

Acknowledgments-This work was supported by NSF EAR-8904788 and OCE-9018136. The author thanks C. Xenophontos for invaluable logistical assistance during sampling of the drillcore, A. Arquit for assistance in sampling the core, $J$. Burdett for help in the lab, and D. Teagle for providing the outcrop samples. Discussions with D. Teagle and K. Gillis and helpful reviews by D. Crowe, D. Huston, D. Janecky, and M. Kusakabe led to significant improvements in the manuscript.

Editorial handling: B. E. Taylor

\section{REFERENCES}

Abrajano T. A. and Pasteris J. D. (1989) Zambales Ophiolite Philippines II. Sulfide petrology of the critical zone of the Acoje Massif. Contrib. Mineral. Petrol. 103, 64-77.

ADAmides N. G. (1987) Diverse modes of occurrence of Cyprus sulphide deposits and comparison with recent analogues. In Cyprus Crustal Study Project: Initial Report, Holes $\mathrm{Cy}-2$ and $2 a$ (ed. P. T. RoBinson et al.); Geol. Surv. Canada Paper 85-29, pp. 153-168.

ADAMIDES N. G. (1990) Hydrothermal circulation and ore deposition in the Troodos ophiolite, Cyprus. In Ophiolites and Oceanic Lithosphere (ed. J. MalPaS et al.), pp. 685-704. Geol. Survey Cyprus.

ALT J. C. (1991) Sulfur isotopic profile through the Troodos ophiolite, Cyprus: Preliminary results and implications. In Ophiolite Genesis and Evolution of the Oceanic Lithosphere (ed. TJ. PETERS et al.), pp. 427-443. Kluwer.

ALT J. C. and ANDERson T. F. (1991) The mineralogy and isotopic composition of sulfur in 1 ayer 3 gabbros from the Indian Ocean, ODP Hole 735B. In Proc. Ocean Drilling Program, Scientific Results (ed. P. T. RoBinson et al.), Vol. 118, pp. 113-125. Ocean Drilling Program. 
ALT J. C. and CHAussidon M. (1989) Ion microprobe analyses of the sulfur isotopic composition of sulfides in hydrothermally altered rocks, DSDP/ODP Hole 504B. In Proc. ODP. Scientific Results (ed. K. BECKER et al.), Vol. 111, pp. 41-46. Ocean Drilling Program.

Alt J. C., Honnorez J., Laverne C., and EmmermanN R. ( 1986) Hydrothermal alteration of a $1 \mathrm{~km}$ section through the upper oceanic crust, DSDP Hole 504B: The mineralogy, chemistry, and evolution of seawater-Basalt interactions. J. Geophys. Res. 91, 10,309-10,335.

ALT J. C., ANDERSON T. F., and BONNELL L. (1989) The geochemistry of sulfur in a $1.3 \mathrm{~km}$ section of hydrothermally altered oceanic crust, DSDP Hole 504B. Geochim. Cosmochim. Acta 53, 10111023.

Alt J. C., Shanks W. C., and JaCkson M. C. (1993) Sources and cycling of sulfur in subduction zones: The Mariana island arc and back arc trough. Earth Planet. Sci. Lett. 119, 477-494.

ANDREWS A. J. (1979) On the effect of low-temperature seawaterbasalt interaction on the distribution of sulfur in oceanic crust, Layer 2. Earth Planet. Sci. Lett. 46, 68-80.

ARNold M. and ShepPard S. M. F. (1981) East Pacific Rise at latitude $21^{\circ} \mathrm{N}$ : Isotopic composition and origin of the hydrothermal sulphur. Earth Planet. Sci. Lett. 56, 148-156.

BARAGAR W. R., LAMBERT M. B., BAGLOW N., and GiBSON I. (1989) Sheeted dikes from CY4 and surface sections: Troodos ophiolite. In Cyprus Crustal Study Project: Initial Report, Hole CY-4 (ed. I. L. GiBSON et al.), pp. 69-106.

BEDNARZ U. and SCHMINCKE H. U. (1989) Mass transfer during sub-seafloor alteration of the upper Troodos crust, Cyprus. Contrib. Mineral. Petrol. 102, 93-101.

BetTison-VARGa L., VARGa R. J., and SChiffman P. (1992) Relation between ore-forming hydrothermal systems and extensional deformation in the Solea graben spreading center, Troodos Ophiolite. Geology 20, 987-990.

BICKLE M. J. and TEAGLE D. A. H. (1992) Strontium alteration in the Troodos ophiolite: Implications for fluid-fluxes and geochemical transport in mid-ocean ridge hydrothermal systems. Earth Planet. Sci. Lett. 113, 219-237.

BiRD D. K., SChifFMan P., Elders W. A., Williams A. E., and MCDOWELL S. D. (1984) Calc-silicate mineralization in active geothermal systems. Econ. Geol. 79, 671-695.

BISCHOFF J. L. and SEYFRIEU W. E. (1978) Hydrothermal chemistry of seawater from 25 to $350^{\circ}$ C. Am. J. Sci. 278, 838-860.

BLuTH G. and Oнмото H. (1988) Sulfur isotope study of sulfidesulfate chimneys on the East Pacific Rise, $11-13^{\circ} \mathrm{N}$ latitude. $\mathrm{Ca}$ nadian Mineral. 26, 505-516.

BOWERS T. S. (1989) Stable isotope signatures of water-rock interaction in mid-ocean ridge hydrothermal systems: Sulfur, oxygen and hydrogen. J. Geophys. Res. 94, 5775-5786.

Canfield D. E., Raiswell R., Westrich J. T., Reaves C. M., and BERNER R. A. (1986) The use of chromium reduction in the analysis of reduced inorganic sulfur in sediments and shales. Chem. Geol. 54, 149-155.

CANN J. R., OAKLEY P. J., RichaRdS H. G., and Richardson C. J. (1987) Geochemistry of hydrothermally altered rocks from Cyprus Drill Holes $\mathrm{Cy}-2$ and $\mathrm{Cy}-2 \mathrm{a}$ compared with other Cyprus Stockworks. In Cyprus Crustal Study Project: Initial Report, Holes Cy2 and $2 a$ (ed. P. T. RoBINSON et al.); Geol. Surv. Canada Paper 85-29, 87-102.

Chamberlain J. A. (1967) Sulfides in the Muskox intrusion. $\mathrm{Ca}$ nadian J. Earth Sci. 4, 105-153.

Chaussidon M. F., Albarede F., and Sheppard S. M. F. (1987) Sulphur isotope heterogeneity in the mantle from ion microprobe measurements of sulphide inclusions in diamonds. Nature $\mathbf{3 3 0}$, 242-244

ClaARK L. A. (1971) Volcanogenic ores: comparison of cupriferous pyrite deposits of Cyprus and Japanese Kuroko deposits. Soc. Mining Geol. Japan Spec. Issue 3, 206-215.

ClaypoOl G. E., Holser W. T., KaPlan I. R., Sakai H., and ZaK I. (1980) The age curves of sulfur and oxygen isotopes in marine sulfate and their mutual interpretation. Chem. Geol. 28, 199-260.

CRAIG J. R. (1973) Pyrite-pentlandite assemblages and other low temperature relations in the Fe-Ni-S system. Amer. J. Sci. 273A, 496-510.

Craig J. R., Vaughan D. J., and Higgins J. R. (1979) Phase relations in the $\mathrm{Cu}-\mathrm{Co}-\mathrm{S}$ system and mineral associations of the carrollite-linnaeite series. Econ. Geol. 74, 657-671.

DING K. and SEYFRIED W. E. (1992) Determination of Fe-Cl complexing in the low pressure supercritical region ( $\mathrm{NaCl}$ fluid): Iron solubility constraints on $\mathrm{pH}$ of subseafloor hydrothermal fluids. Geochim. Cosmochim. Acta 56, 3681-3692.

ECKSTRAND O. R. (1975) The Dumont Scrpentinite: A model for control of nickeliferous opaque mineral assemblages by alteration reactions in ultramafic rocks. Econ. Geol. 70, 183-201.

Edmond J. M., Measures C., McDuff R. E., Chan L. H., Collier R., Grant B., Gordon L. I., and Corliss J. B. (1979) Ridge crest hydrothermal activity and the balances of the major and minor elements in the ocean: The Galapagos data. Earth. Planet. Sci. Lett. 46, 1-18.

FRIEDRICHSEN H. ( 1985 ) Strontium, oxygen, and hydrogen isotope studies on primary and secondary minerals in basalts from the Costa Rica Rift, DSDP Hole 504B, Leg 83. In Init. Repts. DSDP (ed. R. N. ANDERSON et al.), Vol. 83, pp. 289-295. US Gov't. Printing Office.

GILLIS K. M. and RoBINSON P. T. (1990) Patterns and processes of alteration in the lavas and dikes of the Troodos ophiolite, Cyprus. J. Geophys. Res. 95, 21,523-21,548.

Gillis K. M. and Thompson G. (1993) Metabasalts from the MidAtlantic Ridge: New insights into hydrothermal systems in slowspreading crust. Contrib. Mineral. Petrol. 113, 502-523.

HARMON R. S., HOEFS J., and WEDEPOHL K. H. (1987) Stable isotope $(\mathrm{O}, \mathrm{H}, \mathrm{S})$ relationships in Tertiary basalts and their mantle xenoliths from the Northern Hessian Depression, W. Germany. Contrib. Mineral. Petrol. 95, 350-369.

HARPER G., BOWMAN J. R., and KuHNS R. (1988) A field, chemical, and stable isotope study of subseafloor metamorphism of the Josephine Ophiolite, California-Oregon. J. Geophys. Res. 93, 46254656.

HAUGHTON D. R., ROEDER P., and SKINNeR B. J. (1974) Solubility of sulfur in mafic magmas. Econ. Geol. 69, 451-467.

HERZIG P. M. and FRIEDRICH G. H. (1987) Sulfide mineralization, hydrothermal alteration and chemistry in the drill hole CY-2a, Agrokipia, Cyprus. In Cyprus Crustal Study Project: Initial Report, Holes $\mathrm{Cy}-2$ and $2 a$ (ed. P. T. RoBinson et al.); Geol. Surv. Canada Paper 85-29, 103-138.

Holser W. T., SChidlowski M., MACKENZIE F. T., and MAYNARD J. B. (1988) Biogeochemical cycles of carbon and sulfur. In ('hemical Cycles in the Evolution of the Earth (ed. B. GREGOR et al.), Chap. 5, pp. 105-174. Wiley.

HutCHINSON R. W. and SEARLE D. L. (1971) Stratabound pyrite deposits in Cyprus and relations to other sulfide ores. Soc. Mining Geol. Japan Spec Issue 3, 198-205.

JAMIESON H. E. and LYDON J. W. (1987) Geochemistry of a fossil ore solution aquifer: Chemical exchange between rock and hydrothermal fluid recorded in the lower portio of research drill hole CY-2a, Agrokipia, Cyprus. In Cyprus Crustal Study Project: Initial Report, Holes $\mathrm{Cy}$-2 and $2 \mathrm{a}$ (ed. P. T. Robinson et al.); Geol. Surv. Canada Paper 85-29, 139-152.

JANECKY D. S. and SHANKS W. C. III (1988) Computational modeling of chemical and sulfur isotopic reaction processes in seafloor hydrothermal systems: Chimncys, massive sulfides, and subjacent alteration zones. Canadian Mineral. 26, 805-825.

JOHNSON A. E. (1972) Origin of Cyprus pyrite deposits. 24th IGC. 291-298.

KELLEY D. S. and RoBinson P. T. (1990) Development of a brinedominated hydrothermal system at temperatures of $400-500^{\circ} \mathrm{C}$ in the upper level plutonic sequence, Troodos ophiolite, Cyprus. Geochim. Cosmochim. Acta 54, 653-662.

Kusak ABE M., MAYEda S., and NaKamura E. (1990) S, O, and $\mathrm{Sr}$ isotope systematic of active vent material from the Mariana backarc basin spreading axis at $18^{\circ} \mathrm{N}$. Earth Planet. Sci. Lett. 100, 275-282.

MALPAS J. and WILLIAMS D. (1991) Geology of the area surrounding the CY1 and CY1A boreholes. In Cyprus Crustal Study Project: 
Initial Report, Holes CY-I and CYIA (ed. I. L. GIBSoN et al.); Geol. Surv. Canada Paper 90-20, 29-40.

MalPas J., Robinson P. T., and Salisbury M. (1989) Geology and Geophysics of Borehole VY4 of the Cyprus Crustal Study Project: Summary. In Cyprus Crustal Study Project: Initial Report, Hole CY-4 (ed. I. L. GiBSON et al.); Geol. Surv. Canada Paper 889, 381-393.

MisRa K. C. and FleET M. E. (1973) The chemical compositions of synthetic and natural pentlandite assemblages. Econ. Geol. 68, $518-539$.

Muenow D. W., Garcia M. O., Aggrey K. E., Bednarz U., and SCHMINCKE H. U. (1990) Volatiles in submarine glasses as a discriminant of tectonic origin: Application to the Troodos ophiolite. Nature 343, 159-161.

NALDRETT A. J. (1981) Nickel sulfide deposits: classification, composition and genesis. Econ. Geol. (75th Anniversary Vol.) (ed. B. J. SKINNER ), 485-627.

OHMOTO H. and LASAGA A. C. (1982) Kinetics of reactions between aqueous sulfates and sulfides in hydrothermal systems. Geochim. Cosmochim. Acta 46, 1727-1745.

Oнмото H. and RYE R. O. (1979) Isotopes of sulfur and carbon. In Geochemistry of Hydrothermal Ore Deposits (ed. H. L. BARNES), pp. 509-567. Wiley.

RAITENSCHI.FIN M. et al. (1985) Isotopic and trace element composition of volcanic glass from the Akaki canyon, Cyprus: Implications for the origin of the Troodos Ophiolite. Earth Planet Sci Lett. 75, 369-383.

ReEs C. E., JENKInS W. J., and MONSTER J. (1978) The sulphur isotopic composition of ocean water sulphate. Geochim. Cosmochim. Acta 42, 377-381.

Richardson C. J., CanN J. R., Richards H. G., and Cowan J. G. (1987) Metal-depleted root zones of the Troodos ore-forming systems, Cyprus. Earth Planet. Sci. Lett. 84, 243-253.

Robinson P. T., Melson W. G., O'Hearn T., and SChmincke H. U. ( 1983) Volcanic glass compositions of the Troodos Ophiolite, Cyprus. Geology 11, 400-404.

Sakai H., Desmarais D. J., Ueda A., and Moore J. G. (1984) Concentrations and isotope ratios of carbon, nitrogen, and sulfur in ocean-floor basalts. Geochim. Cosmochim. Acta 48, 2433-2441.

SCHIFFMAN P. and SMITH B. M. (1988) Petrology and oxygen isotope geochemistry of a fossil seawater hydrothermal system within the Solea Graben, northern Troodos Ophiolite, Cyprus. J. Geophys. Res. 93, 4612-4624.

SEEWALD J. S. and SEYFRIED W. E. ( 1990 ) The effect of temperature on metal mobility in subseafloor hydrothermal systems: Constraints from basalt alteration experiments. Earth Planet. Sci. Lett. 101, 388-403.

SEYFried W. E., Ding K., and BERNDT M. E. (1988) Phase equilibria constraints on the chemistry of hot spring fluids at mid-ocean ridges. Geochim. Cosmochim. Acta 55, 3559-3580.

SEYFried W. E., BERndT M. E., and SeEWALd J. S. ( 1991 ) Hydrothermal alteration processes at mid-ocean ridges: Constraints from diabase alteration cxperiments, hot-spring fluids and composition of the oceanic crust. Canadian Mineral. 26, 787-804.

Shanks W. C., III, and SEYFried W. E., JR. (1987) Stable isotope studies of vent fluids and chimney minerals, southern Juan de Fuca Ridge: Sodium metasomatism and seawater sulfate reduction. J. Geophys. Res. 92, 11,387-11,399.

Shanks W. C., III, BIschoff J. L., and Rosenbauer R. J. ( 1981 ) Seawater sulfate reduction and sulfur isotope fractionation in basaltic systems: Interaction of seawater with fayalite and magnetite at $200-350^{\circ}$ C. Geochim. Cosmochim. Acta 45, 1977-1995.

SMITH G. C. and VINE F. J. (1987) Seismic velocities in basalts from CCSP drill holes Cy-2 and CY-2a at Agrokipia Mines, Cyprus. In Cyprus Crustal Study Project: Initial Report, Holes $C y-2$ and $2 a$ (ed. P. T. RobInSON et al.); Geol. Surv. Canada Paper 85-29, 295306.

SMITH G. C. and VINE F. J. ( 1989) The physical properties of diabases, gabbros and ultramafic rocks from CCSP drill hole CY4 at Palekhori, Cyprus. In Cyprus Crustal Study Project: Initial Report, Hole CY-4 (ed. I. L. GiBson et al.); Canadian Geol. Surv. Paper $88-9,295-314$

SMITH G. C. and Vine F. J. (1991) Physical properties of basalts from CCSP drillholes CY 1 and CY1A, Akaki Canyon, Cyprus. In Cyprus Crustal Study Project: Initial Report, Holes CY.I and CY1A (ed. I. L. Gibson et al.); Geol. Surv. Canada Paper 90-20. 217232.

STYRT M. M. et al. ( 1981 ) The mineralogy and isotopic composition of sulfur in hydrothermal sulfide/sulfate deposits on the East Pacific Rise, $21^{\circ} \mathrm{N}$ latitude. Earth Planet. Sci. Lett. 53, 382-390.

Thy P., SCHIFFMAN P., and MoORES E. M. (1989) Igneous mineral stratigraphy and chemistry of the Cyprus Crustal Study Project drill core in the plutonic sequences of the Troodos ophiolite. In Cyprus Crustal Study Project: Initial Report, Hole CY-4 (ed. I. L. GiBSON et al.); Canadian Geol. Surv. Paper 88-9, 147-186.

TOMASSON J. and KRISTMANNSDOTTIR H. (1972) High temperature alteration minerals and thermal brines, Reykjanes, Iceland. Contrib. Mineral. Petrol. 36, 123-134.

UeDA A. and SAKAI H. (1984) Sulfur isotope study of quaternary volcanic rocks from the Japanese Islands Arc. Geochim. Cosmochim. Acta 48, 1837-1848.

VIBETTI N. J., KERRICH R., and FYFE W. S. (1989) Oxygen and carbon isotope studies of hydrothermal alteration in the Troodos ophiolite complex, Cyprus. In Cyprus Crustal Study Project: Initial Report, Hole CY-4 (ed. I. L. GIBSON et al.); Canadian Geol. Surv. Paper 88-9, 221-228.

WENNER D. B. and TAYLOR H. P. (1973) Oxygen and hydrogen isotope studies of the sepentinization of ultramafic rocks in oceanic environments and continental ophiolite complexes. Amer. J. Sci. 273, 207-239.

WiLliams D. L. and von Herzen R. P. (1974) Heat loss from the earth: New estimate. Geology 2, 327-328.

Woodhead J. D., Harmon R. S., and Fraser D. G. (1987) O, S, $\mathrm{Sr}$ and $\mathrm{Pb}$ isotope variations in volcanic rocks from the Northern Mariana Islands: Implications for crustal recycling in intra-occanic arcs. Earth Planet. Sci. Lett. 83, 39-52.

WOODRUFF L. G. and SHANKS W. C. III ( 1988) Sulfur isotope study of chimney minerals and vent fluids from $21^{\circ} \mathrm{N}$, East Pacific rise: Hydrothermal sulfur sources and disequilibrium sulfate reduction. J. Geophys. Res. 93, 4562-4572. 